\title{
Complexities of androgen receptor signalling in breast cancer
}

\author{
Keely M McNamara ${ }^{*}$, Nicole L Moore ${ }^{1, *}$, Theresa E Hickey ${ }^{1}$, Hironobu Sasano and \\ Wayne D Tilley ${ }^{1}$
}

Department of Pathology, Tohoku University School of Medicine, Miyagi, Sendai, Japan

1Dame Roma Mitchell Cancer Research Laboratories, Discipline of Medicine, The University of Adelaide and Hanson Institute, DX 650801, Adelaide, South Australia 5005, Australia

* (K M McNamara and N L Moore contributed equally to this work)
Correspondence should be addressed to W D Tilley

Email wayne.tilley@adelaide. edu.au

\begin{abstract}
While the clinical benefit of androgen-based therapeutics in breast cancer has been known since the 1940s, we have only recently begun to fully understand the mechanisms of androgen action in breast cancer. Androgen signalling pathways can have either beneficial or deleterious effects in breast cancer depending on the breast cancer subtype and intracellular context. This review discusses our current knowledge of androgen signalling in breast cancer, including the relationship between serum androgens and breast cancer risk, the prognostic significance of androgen receptor (AR) expression in different breast cancer subtypes and the downstream molecular pathways mediating androgen action in breast cancer cells. Intracrine androgen metabolism has also been discussed and proposed as a potential mechanism that may explain some of the reported differences regarding dichotomous androgen actions in breast cancers. A better understanding of AR signalling in this disease is critical given the current resurgence in interest in utilising contemporary AR-directed therapies for breast cancer and the need for biomarkers that will accurately predict clinical response.
\end{abstract}

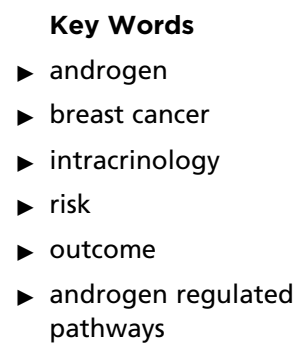

Endocrine-Related Cancer (2014) 21, T161-T181

\section{Introduction}

The importance of androgenic hormones in breast cancer has been recognised for much of the last century. Despite little understanding of their cellular actions in breast tissue at the time, androgenic compounds were used as breast cancer therapies between the 1940s and the 1980s. Although this therapeutic strategy displayed sound clinical efficacy (Tormey et al. 1983, Ingle et al. 1991), the use of androgenbased hormonal therapies fell from favour due to their masculinising side effects in some women and the concurrent development of targeted anti-oestrogenic therapies. With recent insights into the molecular heterogeneity of breast cancers, intracrine steroid metabolism and mechanisms of anti-oestrogen therapy resistance, an appreciation of the role of androgen signalling pathways in breast cancer is experiencing a revival. For example, contemporary pre-clinical studies have led to clinical trials utilising androgen receptor (AR) antagonists as breast cancer therapies for women with metastatic disease. In this review, current knowledge on the role of androgen signalling in breast tumourigenesis will be discussed, indicating the complexities of androgen action in different breast cancer subtypes and the potential to exploit this pathway for successful new therapeutic interventions.

\section{Androgens and breast cancer risk}

Although androgens are commonly considered as male hormones, they are also detected at physiologically

This paper is one of 12 papers that form part of a thematic review section on Androgens and the AR in Breast and Prostate Cancer. The Guest Editors for this section were Wayne Tilley and Frank Elaessens. WI Jilley was pot involved in the handling of : 08 : $06 \mathrm{PM}$ this paper, on which he is listed as an author. 
relevant levels in the circulation of women (Burger 2002, McNamara et al. 2010) and play important biological roles in females. There are several species of androgenic hormones in the circulation including, in the order of high to low concentration, dehydroepiandrosterone-sulphate (DHEAS), DHEA, androstenedione $\left(\mathrm{A}_{4}\right)$, testosterone and $5 \alpha$-dihydrotestosterone (DHT). The potent androgen testosterone and, to a lesser extent, the precursor androgens DHEA and $\mathrm{A}_{4}$ are produced by the ovaries while DHEA, DHEAS, $\mathrm{A}_{4}$ and testosterone are secreted by the adrenal glands. In addition to these endocrine sources, testosterone, DHT and their metabolites are also synthesised in peripheral tissues such as the breast, bone and brain (Labrie et al. 2003). Testosterone levels fluctuate during the menstrual cycle and gradually decline, although not completely, following menopause (Labrie et al. 2003, Rothman et al. 2011). By contrast, adrenal androgen production continues following menopause (Labrie et al. 2003). Both androgens and oestrogens bind to steroid hormone-binding globulin (SHBG) in the circulation, which controls the bioavailability of hormones to the breast and other tissues. Numerous studies have examined the potential role of circulating androgens as risk factors for breast cancer, as discussed in detail below. In general, elevated serum testosterone level has been associated with an increased breast cancer risk in postmenopausal women in some studies; however, results between studies are often contradictory and the relationship remains unclear. This is largely due to the inherent limitations in the techniques used to measure testosterone levels and the difficulty in interpreting these studies in relation to intracrine steroid metabolism (see sections 'Limitations in the measurement and interpretation of serum testosterone levels and breast cancer risk' and 'Intracrine androgen metabolism in the breast').

\section{Premenopausal women}

Nine large-scale prospective cohort studies have examined endogenous serum testosterone levels and breast cancer risk in premenopausal women. Four of these studies showed significantly higher levels of serum testosterone in breast cancer patients compared with controls, while three of these four studies also found a significantly increased breast cancer risk associated with increased testosterone levels (Table 1 and references therein). The remaining studies found no significant association between serum testosterone and breast cancer risk (Table 1). Furthermore, five studies also measured bioavailable testosterone (the component of steroid calculated to be unbound to SHBG), as opposed to total testosterone that also includes the component bound to SHBG. Two of the five studies reported a significant positive association between bioavailable testosterone and breast cancer risk (Supplementary Table S1, see section on supplementary data given at the end of this article). In addition to testosterone, some of these studies also measured DHEAS, $\mathrm{A}_{4}, 17 \beta$-oestradiol $\left(\mathrm{E}_{2}\right)$, oestrone $\left(\mathrm{E}_{1}\right)$ or $\mathrm{SHBG}$, but an association with breast cancer risk was rarely observed for these variables in premenopausal women (Supplementary Table S1).

\section{Postmenopausal women}

The association between endogenous circulating testosterone and breast cancer risk in postmenopausal women has been reported in 11 large-scale prospective cohort studies. The majority of these studies reported that higher levels of circulating testosterone were significantly associated with an increased breast cancer risk (Table 1 and references therein). Similarly, higher levels of other hormones, including free testosterone, DHEAS, $\mathrm{A}_{4}, \mathrm{E}_{2}$ or $\mathrm{E}_{1}$, were associated with an increased breast cancer risk in several of these studies, while reduced levels of SHBG were sometimes associated with a decreased risk of breast cancer (Supplementary Table S1 and references therein). An association between increased testosterone and breast cancer recurrence has also been reported (Berrino et al. 2005). Increased serum testosterone levels in breast cancer cases vs controls were more pronounced in postmenopausal women compared with premenopausal women (Table 1). However, the association between increased androgen levels and breast cancer risk has not been observed in all studies (Hankinson et al. 1998, Adly et al. 2006), with breast cancer risk being ameliorated if the levels of serum oestrogens were taken into account (Table 1), suggesting that the conversion of testosterone into $\mathrm{E}_{2}$ by aromatase activity contributes to the association between testosterone and breast cancer risk (see sections 'Limitations in the measurement and interpretation of serum testosterone levels and breast cancer risk' and 'Intracrine androgen metabolism in the breast'). Additionally, no association has been observed between serum levels of steroids, including testosterone, and the risk of developing ductal carcinoma in situ (DCIS), a putative breast cancer precursor lesion (ZeleniuchJacquotte et al. 2005).

\section{Exogenous androgens}

The link between breast cancer development and androgen treatment has been investigated in patients prescribed androgens for therapeutic purposes. Studies evaluating

Published by Bioscientifica Ltd. 
Table 1 Association between serum testosterone levels and breast cancer risk in prospective studies

\begin{tabular}{|c|c|c|c|c|}
\hline Reference & Cases & Controls & Subgroups & $\begin{array}{l}\text { Testosterone levels in cases as } \\
\text { a percent of control ( } P \text { value) }\end{array}$ \\
\hline \multicolumn{5}{|l|}{ Premenopausal women } \\
\hline $\begin{array}{l}\text { Zeleniuch-Jacquotte } \\
\text { et al. (2012) }\end{array}$ & 274 & 683 & & $108(0.01)$ \\
\hline Dorgan et al. (2010) & 98 & 168 & & $113(0.005)$ \\
\hline \multirow{2}{*}{ Wang et al. (2009) } & 110 & 110 & Follicular & $92(0.235)$ \\
\hline & 116 & 117 & Luteal & $96(0.501)$ \\
\hline \multirow[t]{2}{*}{ Eliassen et al. (2006) } & 190 & 374 & Follicular & $100(0.11)$ \\
\hline & 192 & 390 & Luteal & $103(0.09)$ \\
\hline Kaaks et al. $(2005 a, b)$ & 370 & 726 & & $108(0.01)$ \\
\hline Sturgeon et al. (2004) & 160 & 174 & & 96 (NG) \\
\hline Micheli et al. (2004) ${ }^{a}$ & 65 & 243 & Luteal & NG (NG) \\
\hline Yu et al. (2003) & 127 & 130 & & $110(0.022)$ \\
\hline Thomas et al. (1997) & 68 & 182 & & NG (NG) \\
\hline \multicolumn{5}{|l|}{ Postmenopausal women } \\
\hline Fourkala et al. (2012) & 200 & 400 & & $125(0.04)$ \\
\hline \multirow[t]{2}{*}{ Farhat et al. $(2011)^{c}$} & 111 & 594 & $E R \alpha$ negative & $94(0.16)$ \\
\hline & 206 & & ER $\alpha$ positive & $116(0.004)$ \\
\hline Baglietto et al. (2010) & 857 & 197 & & 100 (NG) \\
\hline Sieri et al. (2009) & 165 & 672 & & $112(0.006)$ \\
\hline Wang et al. (2009) & 139 & 138 & & $121(0.029)$ \\
\hline Kaaks et al. $(2005 a, b)^{a}$ & 677 & 1309 & & $110(<0.001)$ \\
\hline $\begin{array}{l}\text { Zeleniuch-Jacquotte } \\
\text { et al. (2004) }\end{array}$ & 297 & 563 & & $110(0.002)$ \\
\hline Missmer et al. (2004) & 628 & 312 & & $115(<0.001)$ \\
\hline Yu et al. (2003) & 170 & 171 & & $122(0.002)$ \\
\hline Manjer et al. (2003) & 134 & 438 & & $108-110^{\mathrm{e}}(\mathrm{NG})$ \\
\hline Key et al. $(2002)^{f}$ & 633 & 1765 & & NG (NG) \\
\hline
\end{tabular}

\begin{tabular}{|c|c|}
\hline $\begin{array}{l}\text { Hazard or risk } \\
\text { ratio (range) }\end{array}$ & $P$ value \\
\hline $1.70(1.10-2.70)$ & 0.06 \\
\hline $2.90(1.40-6.30)$ & 0.005 \\
\hline $0.77(0.40-1.50)$ & 0.387 \\
\hline $1.07(0.55-2.06)$ & 0.352 \\
\hline $1.80(0.90-3.40)$ & $0.35^{\mathrm{b}}$ \\
\hline $2.00(1.10-3.60)$ & $0.05^{b}$ \\
\hline $1.73(1.16-2.57)$ & 0.01 \\
\hline $0.92(0.50-1.80)$ & NS \\
\hline $2.16(0.60-7.61)$ & 0.28 \\
\hline $1.92(1.00-3.65)$ & $<0.05$ \\
\hline $1.22(0.60-2.40)$ & 0.57 \\
\hline $2.15(1.26-3.17)$ & $0.0006^{b}$ \\
\hline $0.58(0.33-1.02)$ & $0.08^{\mathrm{b}}$ \\
\hline $1.68(1.04-2.07)$ & $0.005^{\mathrm{b}}$ \\
\hline $1.25(0.78-2.01)$ & $0.37^{c}$ \\
\hline $3.13(1.86-5.28)$ & $<0.001^{\mathrm{b}, \mathrm{d}}$ \\
\hline $2.93(1.57-5.49)$ & $0.047^{b}$ \\
\hline $1.85(1.33-2.57)$ & $<0.001$ \\
\hline $2.15(1.29-3.59)$ & $0.005^{b}$ \\
\hline $1.40(0.90-2.20)$ & $0.003^{\mathrm{b}}$ \\
\hline $2.08(1.06-4.09)$ & $<0.05$ \\
\hline $1.48(0.88-2.49)$ & $0.4^{b}$ \\
\hline $2.22(1.59-3.10)$ & $0.001^{\mathrm{b}}$ \\
\hline
\end{tabular}

Bold italics indicate significance $(P<0.05)$. Hazard or risk ratios and Cls given represent the difference between the lowest and the highest brackets of serum testosterone. Data on additional androgenic and oestrogenic serum steroids can be found in Supplementary Table S1. Unless otherwise stated all risk/hazard values are from non-adjusted risk models.

${ }^{a}$ Free testosterone was also assessed, see Supplementary Table S1.

${ }^{{ }^{b}}$ These studies examined the effect of adjusting for $E_{2}$ levels on the risk associated with serum testosterone levels. In Eliassen, Fourkala, Farhat (ER $\alpha$-negative cohort) and Manjer, there was no effect observed with $E_{2}$ adjustment whereas in Farhat (ER $\alpha$-positive cohort), Wang, Zeleniuch-Jacquotte (2004), Missmer and Key, if the levels of risk associated with testosterone were adjusted for $E_{2}$, the significance of testosterone levels diminished.

'Only bioavailable (adjusted for SHBG concentrations) testosterone levels were reported.

dWhen divided into ER $\alpha$-positive and ER $\alpha$-negative subtypes only the ER $\alpha$-positive subtype remains significant.

${ }^{\mathrm{e}}$ Two cohorts with testosterone levels given separately.

${ }^{\mathrm{f}}$ Reanalysis of nine previous studies.

breast cancer risk in postmenopausal women treated with androgens alone for hypoactive sexual disorder, or testosterone in combination with combination oestrogen-progestin hormone replacement therapy (HRT) for treatment of menopausal symptoms, have not definitively indicated an increased risk of breast cancer associated with androgen treatment (reviewed by Braunstein (2007), Krapf \& Simon (2009) and Davis (2010)). However, many of these studies had a relatively short follow-up period ( $<4$ years), which may not be sufficient to observe a change in breast cancer development. Studies at the cellular level show a reduced proliferative index in tissues from women given HRT with added testosterone compared with HRT alone, which suggests a protective effect of androgens in normal breast tissue (Hofling et al. 2007). Similarly, a reduced proliferative index was observed in normal human breast tissues cultured ex vivo when exposed to the most potent androgen, DHT (Eigeliene et al. 2012, Ochnik et al. 2014), further supporting a growth inhibitory effect of androgens.

The effect of exogenous androgen treatments on breast tissue has also been studied in transsexuals undergoing gender reassignment. No increase in breast cancer risk has been reported in male to female (MtoF) or female to male (FtoM) transsexuals compared with the general population (Asscheman et al. 2011). However, the findings in FtoM cases should be interpreted with caution given that gender reassignment surgery, including mastectomy, usually occurs relatively soon ( $<3$ years) after commencing hormone treatment. While this limits the utility of the data from FtoM transsexuals with regard to breast cancer risk, the mastectomy tissue from these individuals

Published by Bioscientifica Ltd. 
provides a unique opportunity to examine the effects of long-term androgen treatment on breast tissue morphology, cellular proliferation and gene expression. In these tissues, no morphological changes associated with breast cancer risk were observed (Burgess \& Shousha 1993, Shufelt \& Braunstein 2008). While microarray studies examining gene expression profiles have indicated that there are some common immune-, stroma- and epithelialrelated gene expression signatures present in both FtoM breast tissues and malignant breast tissue, the functional significance of these pathways to breast carcinogenesis is yet to be determined (Bentz et al. 2010). Breast cancer cases have been reported in MtoF transsexuals, but they are extremely rare (Mueller \& Gooren 2008, Asscheman et al. 2011). This suggests that prior exposure to male levels of circulating androgens earlier in life may potentially protect against breast cancer development later in life, although further studies with a larger sample size are required to confirm this observation.

\section{Limitations in the measurement and interpretation of serum testosterone levels and breast cancer risk}

As outlined above, studies to date have not provided consistent data on the association between testosterone and breast cancer risk. This is largely due to the limitations in the techniques used for measurement of testosterone and the difficulties associated with their interpretation. Most importantly, the conversion of testosterone to $\mathrm{E}_{2}$ by the aromatase enzyme in breast tissue is unaccounted for in the majority of studies investigating testosterone and breast cancer risk (reviewed by Shufelt \& Braunstein (2008)). Therefore, it is not clear as to whether circulating testosterone is a risk factor per se or a surrogate for increased local production of $\mathrm{E}_{2}$, which directly drives tumour growth. Given the complex intracrine metabolism of steroids that takes place in breast tissue (see section 'Intracrine androgen metabolism in the breast'), levels of serum androgens are a relatively crude predictor of intracellular androgen action, and tissue levels of androgen may have more prognostic value, although this is yet to be explored. In addition, a number of study design factors may explain the discrepancies between reports examining serum testosterone levels and breast cancer risk. Sample size probably contributes to contradictions regarding the significance of androgens in determining breast cancer risk as larger studies have more statistical power to detect smaller differences as significant (Yu et al. 2003, Sturgeon et al. 2004, Kaaks et al. 2005a, Eliassen et al. 2006). The methodology used for measuring testosterone is also important as at any one time, only a small percentage $(\sim 2 \%)$ of circulating testosterone is free and available for uptake into cells (Rothman et al. 2011), while the remainder is sequestered to SHBG and biologically unavailable for cellular uptake and receptor binding. To date, all large-scale studies have used immunoassays to measure serum testosterone levels, which have known limitations in sensitivity and specificity (Harwood \& Handelsman 2009). Mass spectrometry is emerging as a more accurate method for measuring testosterone compared with immunoassays, and the use of this methodology may potentially provide clearer information regarding testosterone and breast cancer risk. Immunoassays also do not directly measure levels of free testosterone, which is instead measured indirectly through calculations based on independent measurements of total testosterone and SHBG; the accuracy of this method is under debate (de Ronde et al. 2006, Sartorius et al. 2009). In some studies (Missmer et al. 2004, Zeleniuch-Jacquotte et al. 2012), this calculation has strengthened the significance of the risk association between testosterone and breast cancer (Supplementary Table S1 and references therein). Another complicating factor in premenopausal women is the variation in testosterone levels across the menstrual cycle; mass spectrometry analyses show that there is a statistically significant increase in testosterone levels at the mid-cycle corresponding to the ovulatory peak of $\mathrm{E}_{2}$ from the ovaries (Rothman et al. 2011, Bui et al. 2013). While this intraindividual cyclic difference in testosterone is small in comparison to the variation in testosterone observed at a population level (Braunstein et al. 2011), one study has suggested that the mid-cycle peak may demonstrate an association of testosterone and breast cancer risk that is not observed at other stages (Eliassen et al. 2006).

\section{Prognostic value of AR expression in breast cancer}

The AR, the intracellular receptor that mediates the biological effects of androgens, has been detected in up to $85 \%$ of primary breast cancers and up to $75 \%$ of metastatic lesions (Lea et al. 1989, Moinfar et al. 2003, Park et al. 2010, Honma et al. 2013), although as discussed below, this frequency varies between different breast cancer subtypes. The majority of studies investigating the relationship between AR levels in the primary tumour, clinical characteristics and disease outcome have found that AR expression is a favourable prognostic indicator (reviewed by Hickey et al. (2012)). In cohorts not selected on the basis of estrogen receptor- $\alpha$ (ER $\alpha$ (ESR1)) status,

Published by Bioscientifica Ltd. 
AR positivity has been associated with longer relapse-free, metastasis-free and overall survival, smaller tumour size and lower histological grade (Bryan et al. 1984, Langer et al. 1990, Kuenen-Boumeester et al. 1992, Soreide et al. 1992, Schippinger et al. 2006, Agrawal et al. 2008, Gonzalez et al. 2008, Hanley et al. 2008, Ogawa et al. 2008, Soiland et al. 2008, Park et al. 2010, Yu et al. 2011, Peters et al. 2012, Honma et al. 2013). High AR levels have also been associated with a favourable response to chemotherapy and hormonal therapy, including antioestrogens, aromatase inhibitors and progestins (Teulings et al. 1980, Bryan et al. 1984, Birrell et al. 1995, Agrawal et al . 2008, Chintamani et al. 2010, Chanplakorn et al. 2011, Loibl et al. 2011). Importantly, AR has also been shown to be an independent predictor of relapse-free, metastasis-free and/or overall survival in some studies (Soreide et al. 1992, Gonzalez et al. 2008, Soiland et al. 2008, Yu et al. 2011). However, other studies have shown that AR levels do not predict the response to endocrine therapy or relapse-free or overall survival (Allegra et al. 1979, Soreide et al. 1992, Carreno et al. 2007). Discrepancies in study results could be explained by multiple factors, including the following: i) the use of tissue microarrays vs whole-tissue sections; ii) use of different $\mathrm{AR}$ protein detection techniques (radioligand binding, immunohistochemistry (IHC) or reverse-phase protein array); iii) use of different antibodies for AR immunodetection; iv) measurement of $A R$ mRNA via different platforms in transcriptome profiling studies; v) use of different cut-off scores to define AR positivity and vi) differences in clinical parameters such as sample size, prior treatment regimens, length of follow-up and tumour type. Two recent meta-analyses have reported that AR expression is associated with better breast cancer outcomes (Qu et al. 2013, Vera-Badillo et al. 2014). However, numerous shortcomings associated with these analyses, most notably the exclusion of several key studies, limit their use in further clarifying the prognostic value of AR.

Given the high degree of heterogeneity in breast cancer, the role of AR should be considered in the context of the different subtypes of disease. In the general diagnostic setting, IHC analysis of $\mathrm{ER} \alpha$, progesterone receptor (PR (PGR)) and human epidermal growth factor receptor 2 (HER2 (ERBB2)) in tumour samples is routinely performed to categorise tumours as ER $\alpha$-positive, HER2-overexpressing or triple-negative (ER $\alpha$-negative, PR-negative and HER2negative) tumours. This enables selection of patients for anti-oestrogen or anti-HER2 therapies. Recently, gene expression profiling and other bioinformatic approaches performed in a research setting have identified a more complex array of breast cancer molecular subtypes, including luminal A, luminal B, HER2, molecular apocrine (luminal AR, LAR) and basal (Perou et al. 2000, Sorlie et al. 2001, Farmer et al. 2005, Parker et al. 2009, Lehmann et al. 2011, Perou 2011, Curtis et al. 2012), which can predict prognosis and will facilitate the development of new opportunities for more personalised therapies. Studies examining the prognostic value of AR expression in specific breast cancer subtypes are described below.

\section{ER $\alpha$-positive breast cancer}

ER $\alpha$-positive cancers are currently defined by the detection of ER $\alpha$ in at least $1 \%$ of cells within the tumour (Hammond et al. 2010) and make up 75\% of all breast cancers. ER $\alpha$-positive cancers are more likely to be AR positive compared with other types of breast cancer (Gonzalez-Angulo et al. 2009, Peters et al. 2009, Luo et al. 2010, Micello et al. 2010, Niemeier et al. 2010, Park et al. 2010, 2011, Hu et al. 2011, Loibl et al. 2011, Yu et al. 2011). In the majority of studies, AR expression in ER $\alpha$-positive tumours has been associated with favourable characteristics such as improved relapse-free survival, overall survival, response to endocrine treatments and chemotherapy, older age at diagnosis, lower tumour grade, lower Ki67 positivity, smaller tumour size and less necrosis (Gonzalez-Angulo et al. 2009, Peters et al. 2009, Castellano et al. 2010, Niemeier et al. 2010, Hu et al. 2011, Park et al. 2011, 2012, Honma et al. 2013, Witzel et al. 2013). AR expression was also associated with improved overall survival for women with ER $\alpha$-positive breast cancers in both meta-analysis studies (Qu et al. 2013, Vera-Badillo et al. 2014). In some of these studies, multivariate analyses have demonstrated that $\mathrm{AR}$ is an independent predictor of reduced risk of relapse and/or death (Gonzalez-Angulo et al. 2009, Peters et al. 2009, Castellano et al. 2010, Park et al. 2011, 2012). A prognostic index incorporating scores for AR positivity (>1\%), small tumour size and lack of lymph node involvement has been used to predict good prognosis in ER $\alpha$-positive cancers (Castellano et al. 2013).

ER $\alpha$-positive tumours can be further classified into luminal A and luminal B subtypes and some studies have specifically examined AR in these cancers. AR expression has been reported to be highest in luminal-type cancers, with luminal A cancers expressing AR more frequently than luminal B (Collins et al. 2011, Yu et al. 2011). Nevertheless, AR expression in both luminal A and luminal B cancers is associated with a reduced risk of relapse and longer survival (Yu et al. 2011). In luminal B cancers, AR positivity has been associated with increased time to relapse and diseasespecific survival (Castellano et al. 2010).

Published by Bioscientifica Ltd. 
Despite this apparently positive role for AR in ER $\alpha$ positive breast cancers, some studies suggest that high AR expression may be detrimental in tamoxifen-treated breast cancers, potentially contributing to tamoxifen resistance. There is some evidence that tamoxifen-resistant tumours express higher levels of AR than tamoxifen-sensitive tumours (De Amicis et al. 2010), while a high ratio of AR in comparison to $\mathrm{ER} \alpha$ has recently been associated with an increased risk of failure of tamoxifen therapy (Cochrane et al. 2014). These findings suggest that AR may have context-dependent roles in ER $\alpha$-positive breast cancer that can be influenced by prior hormonal therapies.

The generally favourable prognostic indication associated with AR expression in many studies of ER $\alpha$-positive breast cancers is consistent with the predominantly inhibitory effect of androgen treatment on proliferation of ER $\alpha$-positive breast cancer cell lines. The main cell line models used to study ER $\alpha$-positive breast cancer have been the MCF7, ZR-75-1 and T-47D cell lines, which have a luminal molecular phenotype and express AR to some degree (Neve et al. 2006, Kao et al. 2011). Numerous studies have shown that androgens consistently inhibit basal and oestrogen-induced proliferation of the ZR-75-1 and T-47D breast cancer cell lines (Poulin et al. 1988, Birrell et al. 1995, Lapointe et al. 1999, Ortmann et al. 2002, Cops et al. 2008). The effects of androgen treatment in the MCF7 cell line are more variable, with reports of androgens both stimulating and inhibiting proliferation (reviewed by Hickey et al. (2012)). This may relate to differences in AR levels with passage number of the cells, culture conditions that influence AR expression or the variation in steroid receptor levels that is documented in different sub-lines of MCF7 (Horwitz et al. 1978). Furthermore, the ratio of $\mathrm{AR}: \mathrm{ER} \alpha$ expression can influence the response to androgens; increasing the AR:ER $\alpha$ ratio through overexpression of $\mathrm{AR}$ inhibits $\mathrm{E}_{2}$-induced proliferation in $\mathrm{T}-47 \mathrm{D}$ and MCF7 breast cancer cells (Szelei et al. 1997, Peters et al. 2009). The molecular interactions between $A R$ and $E R \alpha$ are discussed further in section 'AR and $\mathrm{ER} \alpha$ '.

\section{ER $\alpha$-negative breast cancer}

ER $\alpha$-negative breast cancers comprise $\sim 30 \%$ of all breast cancers and are typically more aggressive and have poor survival prognoses compared with ER $\alpha$-positive tumours (Barcellos-Hoff 2013). AR expression in ER $\alpha$-negative breast cancer is correlated with a lower Nottingham grade and apocrine differentiation (Niemeier et al. 2010). The association between AR and survival is not so clear in $\mathrm{ER} \alpha$-negative breast cancers as in $\mathrm{ER} \alpha$-positive breast cancers; studies have reported either no association (Gonzalez et al. 2008, Peters et al. 2009, Hu et al. 2011, Park et al. 2011) or an association with improved survival (Agoff et al. 2003, Luo et al. 2010, Witzel et al. 2013). In addition, one meta-analysis reported that $\mathrm{AR}$ is associated with improved overall survival in ER $\alpha$-negative breast cancer ( $\mathrm{Qu}$ et al. 2013), while the other reported no association (Vera-Badillo et al. 2014). A possible explanation for these contradictory results is that ER $\alpha$-negative cancers display a high degree of histological and molecular heterogeneity, necessitating larger cohort numbers to determine a role for AR in specific subtypes of ER $\alpha$-negative disease. Studies examining AR in specific ER $\alpha$-negative breast cancer subtypes are discussed below.

Molecular apocrine breast cancer The molecular apocrine subtype is characterised by high expression of AR and a gene expression profile that closely resembles that of luminal breast cancer, despite being ER $\alpha$-negative (Farmer et al. 2005, Doane et al. 2006, Iggo 2011). While breast cancers defined as molecular apocrine tend to be enriched for HER2 + tumours, not all display this feature. Molecular apocrine tumours that lack HER2 + are probably similar to the LAR subtype of triple-negative breast cancers (TNBCs) (Lehmann et al. 2011). No studies have examined the prognostic significance of AR levels specifically in molecular apocrine breast cancers, in part because these tumours represent $\sim 12 \%$ of all breast cancers and such analyses would necessitate large cohorts of unselected cases. However, molecular apocrine cancers are highly aggressive and have a poor prognosis, comparable to that of basal cancers (Lehmann-Che et al. 2013). Given that AR expression is a defining feature of molecular apocrine breast cancers, it is feasible that AR may, at least in part, contribute to poor prognosis in this subtype. This concept is supported by in vitro studies that demonstrate that $\mathrm{AR}$ signalling promotes proliferation of cell line models of molecular apocrine breast cancer. To date, the MDAMB-453 cell line has been the most widely used model of AR-positive, ER $\alpha$-negative breast cancer and has been classified as molecular apocrine (or LAR) by gene expression profiling (Doane et al. 2006, Lehmann et al. 2011). Proliferation of MDA-MB- 453 cells is stimulated by androgens (Hall et al. 1994, Birrell et al. 1995, Doane et al. 2006, Ni et al. 2011) and inhibited by AR antagonists or AR silencing (Birrell et al. 1995, Lehmann et al. 2011, Robinson et al. 2011). The AR cistrome in MDA-MB-453 cells has been shown to be more similar to that of ER $\alpha$ in MCF7 cells than AR in LNCaP prostate cancer cells (Robinson et al. 2011). This suggests that AR may act as a

Published by Bioscientifica Ltd. 
surrogate ER $\alpha$ in molecular apocrine breast cancer, potentially explaining its oncogenic role in this breast cancer subtype. These studies have formed the basis for trials of the AR antagonist bicalutamide (NCT00468715) and the new generation compound enzalutamide (NCT01889238 and NCT02091960) as therapy for ER $\alpha$-negative, AR-positive metastatic breast cancer. However, a mutation in the ligand-binding domain of the $A R$ in MDA-MB-453 cells compromises receptor activity in response to androgens (Moore et al. 2012). This may limit the utility of this cell line as a model of molecular apocrine breast cancer, necessitating analysis of AR function in additional pre-clinical models of this disease subtype to inform development of suitable therapeutic strategies. Proliferation of other TNBC cell lines classified as LAR, including SUM185PE and CAL-148, has also been shown to be induced by androgen signalling and inhibited by the AR antagonist bicalutamide (Lehmann et al. 2011, Ni et al. 2011). However, the MFM-223 cell line is also classified as LAR, but unlike MDA-MB-453 cells it is inhibited by androgen and not sensitive to bicalutamide, although $A R$ knockdown reduces colony formation (Hackenberg et al. 1991, Lehmann et al. 2011). The divergent proliferative effects of androgens on different in vitro models of AR-positive ER $\alpha$-negative breast cancer probably reflects the heterogeneity of ER $\alpha$-negative disease and suggests that not all ER $\alpha$-negative AR-positive breast cancers will benefit from therapies that inhibit AR activity. This is further supported by a clinical trial in ER $\alpha$-negative, AR-positive metastatic TNBCs, for which the clinical benefit rate for bicalutamide was only 19\% (Gucalp et al. 2013). Therefore, AR expression is not sufficient to identify patients suitable for AR-targeting therapies and characterisation of additional markers of favourable response to these therapies is required.

HER2 + breast cancer The HER $2+$ subtype is enriched for tumours that overexpress HER2 (via gene amplification or dysregulation) and the majority ( 70\%) are ER $\alpha$ negative (Prat \& Perou 2011). HER2-overexpressing tumours are more likely to express AR than other ER $\alpha$ negative subtypes (Micello et al. 2010, Niemeier et al. 2010, Park et al. 2011), suggesting an association between HER2 and AR in these cancers, although this is not observed in all studies (Kollara et al. 2001, Park et al. 2010). There is a growing body of evidence suggesting that crosstalk between AR and HER2 signalling is an important growth regulatory mechanism in ER $\alpha$-negative breast cancer (see section 'AR, FOXA1 and HER2'). Despite this,
AR expression is not associated with survival in HER2overexpressing ER $\alpha$-negative breast cancers (GonzalezAngulo et al. 2009, Micello et al. 2010, Yu et al. 2011), indicating the deficiencies in our understanding of the role of AR in this disease subtype.

Triple-negative breast cancer TNBCs generally have a very low frequency of AR expression compared with other breast cancer subtypes, with as few as $12 \%$ of TNBC patients expressing AR (Gonzalez-Angulo et al. 2009, Luo et al. 2010, Niemeier et al. 2010, Park et al. 2010, 2011, Loibl et al. 2011, Yu et al. 2011, Qi et al. 2012, Tsutsumi 2012, Gucalp et al. 2013). In some studies, AR does not predict survival in TNBCs (Gonzalez-Angulo et al. 2009, Micello et al. 2010, McNamara et al. 2013a). However, in other studies, AR expression in TNBCs is associated with a better disease-free and overall survival as well as other favourable tumour characteristics such as lower grade, lower mitotic score, less frequent metastasis and tumour recurrence (Rakha et al. 2007, Loibl et al. 2011, He et al. 2012, Mrklic et al. 2012, Tang et al. 2012, McNamara et al. 2013a,b) as well as improved response to some chemotherapeutic agents in vitro (Koo et al. 2009). Three studies specifically investigating TNBCs were included in the meta-analysis, which showed that AR expression was associated with worse overall survival but had no significant effect on disease-free survival (Qu et al. 2013). These studies demonstrate that the prognostic significance of AR in TNBCs is yet to be clarified.

Basal breast cancer Basal breast cancers, which account for $\sim 90 \%$ of TNBCs, are often ER $\alpha$ negative, PR negative and lack HER2 amplification; however, gene expression profiling demonstrates that basal breast cancers and TNBCs are not synonymous (Cleator et al. 2007, Badve et al. 2011). The frequency of AR positivity is lowest in basal breast cancers (Collins et al. 2011), where AR expression is associated with a reduced risk of relapse and longer survival (Yu et al. 2011). A recent study has suggested that unlike the non-basal TNBCs, there is no association between AR and lower Ki67 index in AR-expressing basal-like TNBCs (McNamara et al. 2014), indicating the need to better understand AR action in this subtype.

\section{Androgen-regulated pathways in breast cancer}

Recent studies investigating androgen action in breast cancer cell lines have identified several key proteins and signalling pathways that can modulate AR activity and/or mediate the phenotypic outcomes of AR action, including

Published by Bioscientifica Ltd. 
FOXA1, PI3K/AKT/MAPK, PTEN, p53 and cell cycle regulators. Interestingly, some of these proteins have been identified as the most frequently dysregulated pathways in breast cancers when analysed by multiple profiling platforms (Cancer Genome Atlas 2012). In addition to these signalling networks, AR also functionally interacts with the ER $\alpha$ and HER2 signalling pathways to regulate breast cancer cells. A summary of these interactions, including how they crosstalk with each other in addition to $\mathrm{AR}$, and the impact this has on proliferation, is depicted in Fig. 1.

\section{$A R$ and $E R \alpha$}

$\mathrm{AR}$ and ER $\alpha$ signalling crosstalk has been demonstrated in multiple luminal breast cancer cell lines and this mediates the inhibitory effect of AR signalling on proliferation of $\mathrm{ER} \alpha$-positive breast cancer cells (see section 'ER $\alpha$ positive breast cancer'). In particular, ligand-activated $\mathrm{AR}$, or overexpression of constitutively active $\mathrm{AR}$, has been shown to inhibit ER $\alpha$ activity in ZR-75-1, T-47D and MCF7 breast cancer cell lines (Lapointe et al. 1999, Panet-Raymond et al. 2000, Ando et al. 2002, Peters et al. 2009, Need et al. 2012). This inhibitory effect of AR on ER $\alpha$ activity requires the DNA-binding domain of the AR, and in part appears to involve competition with $\mathrm{ER} \alpha$ for binding to regulatory regions of $\mathrm{ER} \alpha$ target genes (Fig. 1A; Peters et al. 2009, Need et al. 2012). These findings provide mechanistic insight into the importance of the AR:ER $\alpha$ expression ratio in the regulation of breast cancer cell proliferation and clinical outcome (see section 'ER $\alpha$ positive breast cancer') (Ando et al. 2002, Peters et al. 2009, Cochrane et al. 2014). Interestingly, the steroid receptor co-activator ARA70 (NCOA4) is influenced by the $\mathrm{AR}: \mathrm{ER} \alpha$ ratio; in the presence of low levels of androgens, ARA70 enhances oestrogen-dependent gene expression in

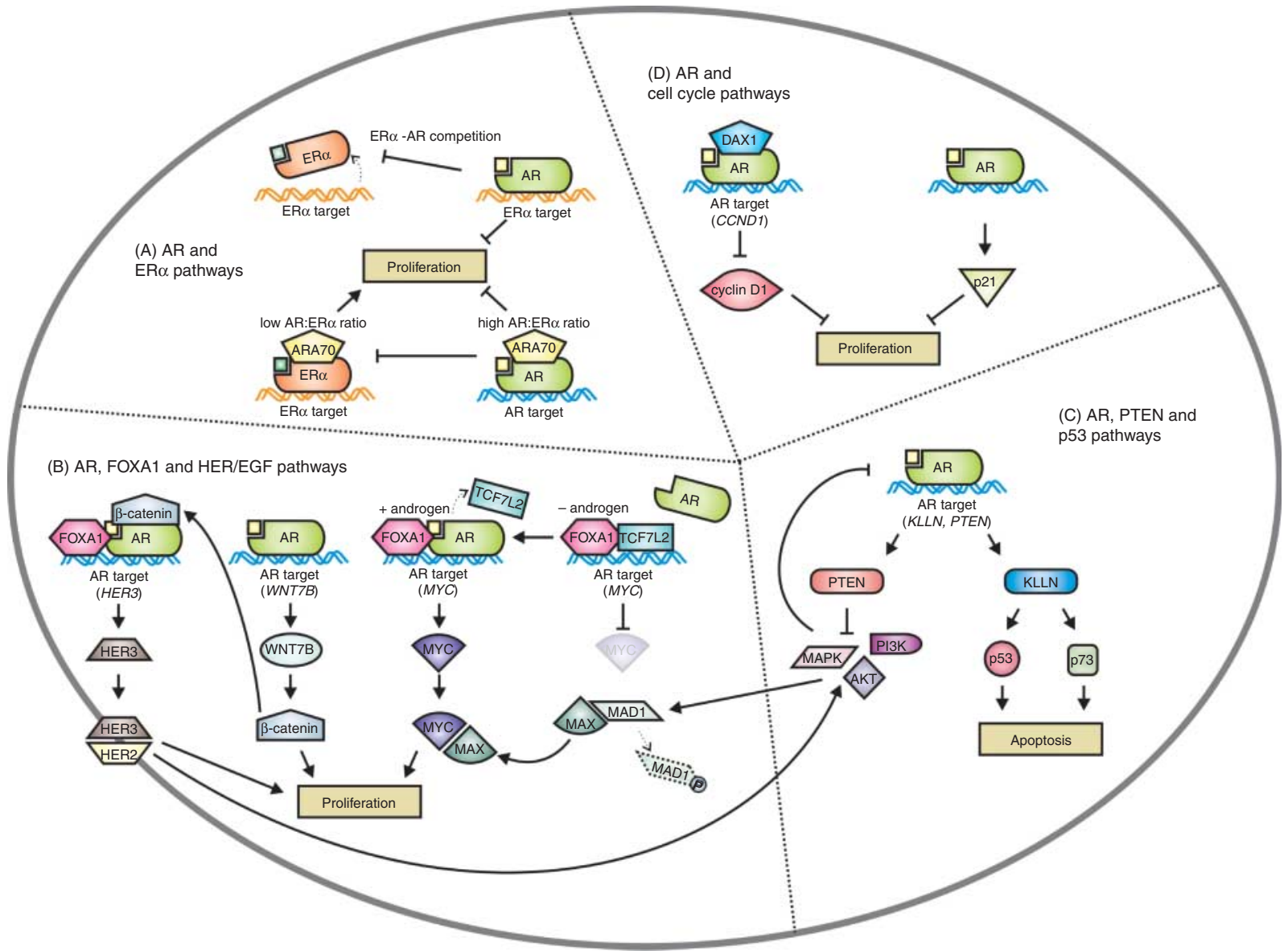

Figure 1

Overview of known pathways regulated by AR to control breast cancer cells. The pathways are divided into the corresponding text in the manuscript in section 'Androgen regulated pathways in breast cancer'.
(A) AR and ER $\alpha$, (B) AR, FOXA1 and HER2, (C) AR, PTEN and p53 and (D) AR and cell cycle regulators. http://erc.endocrinology-journals.org DOI: $10.1530 /$ ERC-14-0243
(C) 2014 Society for Endocrinology Printed in Great Britain
Published by Bioscientifica Ltd 
MCF7 cells; however, upon AR overexpression, ARA70 interacts with $\mathrm{AR}$ to antagonise $\mathrm{ER} \alpha$ signalling (Fig. 1A; Lanzino et al. 2005). This suggests that coactivators play an important role in mediating the phenotypic outcomes of cells with different $\mathrm{AR}: \mathrm{ER} \alpha$ ratios.

\section{AR, FOXA1 and HER2}

FOXA1, a member of the forkhead family of pioneer factors, is a major regulator of DNA binding capacity for $\mathrm{ER} \alpha$ and $\mathrm{AR}$ in breast and prostate cancer cells, respectively (Augello et al. 2011, Robinson \& Carroll 2012). Recent studies have also highlighted the role of FOXA1 in mediating AR DNA binding in ER $\alpha$-negative breast cancer cells (Ni et al. 2011, Robinson et al. 2011). In the MDAMB-453 molecular apocrine breast cancer cell line, there is a high overlap of FOXA1 and AR DNA-binding sites, particularly near androgen-regulated genes (Ni et al. 2011, Robinson et al. 2011). Furthermore, FOXA1 ablation reduces MDA-MB-453 colony formation (Robinson et al. 2011) and blocks androgen induction of the oncogenic transcription factor MYC (Ni et al. 2013). In the absence of AR activation in an ER $\alpha$-negative breast cancer context, FOXA1 interacts with TCF7L2 on DNA to repress AR target genes, whereas upon hormone stimulation, AR replaces TCF7L2 in the FOXA1 complex, leading to induction of gene transcription (Fig. 1B; Ni et al. 2013).

In ER $\alpha$-negative MDA-MB-453 cells, androgens induce expression of WNT7B and HER3, leading to activation of the Wnt/ $\beta$-catenin and HER2 signalling pathways (Fig. 1B), which are required for androgen-induced growth of these cells (Ni et al. 2011). DHT-induced HER2 signalling also induces PI3K/AKT pathway activation, in turn leading to phosphorylation and degradation of MAD1 (MXD1), which disrupts the MAD1-MAX complex (Ni et al. 2013). This allows MAX to interact with MYC, also directly induced by DHT via an AR-FOXA1 interaction (Fig. 1B), leading to enhanced oncogenic function of MYC (Ni et al. 2013). Consistent with the functional interactions between FOXA1 and HER2, FOXA1 is more frequently expressed in HER2-amplified breast cancers compared with HER2negative breast cancers, and HER2 signalling results in the induction of FOXA1 expression (Naderi et al. 2012).

Androgens also enhance activation of ERK, a downstream effector of HER2, and HER2-AR crosstalk is required for proliferation and viability of molecular apocrine breast cancer cell lines (Naderi \& Hughes-Davies 2008, Chia et al. 2011, Naderi et al. 2011), a concept that is supported by bioinformatic analysis of gene expression profiles in molecular apocrine breast cancer tissues
(Sanga et al. 2009). This reveals that AR and FOXA1 utilise a complex regulatory network to enhance the tumourigenic potential of breast cancer cells, at least in a molecular apocrine context.

In ER $\alpha$-positive ZR-75-1 breast cancer cells, FOXA1 binding sites collocate with AR-binding sites, although to an extent lesser than that observed for ER $\alpha$ (Need et al. 2012). Little, however, is known about the importance of FOXA1 for AR DNA binding in an ER $\alpha$-positive context. AR signalling generally has a suppressive effect on cell growth in ER $\alpha$-positive AR-positive breast cancer cells, and studies to date have associated FOXA1 with mitogenic effects of both $\mathrm{AR}$ and $\mathrm{ER} \alpha$ in prostate and breast cancer cells. Therefore, a potential role for FOXA1 in mediating the protective effects of AR on ER $\alpha$-positive breast cancer is not well defined.

\section{AR, PTEN, p53 and PI3K/AKT}

In ER $\alpha$-negative MDA-MB-453 cells, DHT induces PTEN, a tumour suppressor that inhibits PI3K enzymes (Mester \& Eng 2013), via AR binding to an androgen-responsive element in the PTEN upstream promoter (Fig. 1C; Wang et al. 2011). AR-mediated up-regulation of PTEN in breast cancer may form part of a closed feedback loop where PTEN represses PI3K action, which in turn reduces AR activity (Fig. 1C). Interestingly, PTEN shares a bidirectional promoter with another tumour suppressor, KLLN, which is also up-regulated by androgens in ER $\alpha$-negative MDA-MB-453 and ER $\alpha$-positive MCF7 cell lines (Wang et al. 2013a,b). Downstream KLLN actions include induction of p53 (TP53) and p73 (TP73), which promote apoptosis (Fig. 1C). In interpreting these results, it is worth noting that these authors (Wang et al. 2013a,b) report an anti-proliferative effect of androgen treatment in these cell lines, in contrast to a number of other studies that report proliferative effects of androgen (Hackenberg et al. 1988, 1993, Maggiolini et al. 1999, Birrell et al. 1995, Ni et al. 2011, Robinson et al. 2011). Although the reasons for these discrepancies are unknown, this indicates the potential for dualistic effects of AR signalling in MDA-MB-453 and MCF7 breast cancer cell lines. Furthermore, induction of these tumour suppressor genes by DHT is consistent with the anti-proliferative effects of DHT observed by these authors in these cell lines (Wang et al. 2013a,b) and provides mechanistic insight into the genes and pathways that mediate the proliferative effects of androgens in breast cancer. DHT induced p53 expression in MCF7 breast cancer cells (Wang et al. 2013a,b), while AR expression has been associated with a lack of p53 expression in unselected

Published by Bioscientifica Ltd. 
human breast cancers (Ogawa et al. 2008). However, in a different cohort that was separated into ER $\alpha$-positive or $\mathrm{ER} \alpha$-negative disease, no association between AR and p53 was observed in either group (Agoff et al. 2003). Therefore, while there is some evidence to support the functional interactions among AR, PTEN and p53, further studies are required to clarify the role of this pathway in breast cancer cells.

Additional studies support a functional association between AR and the PI3K/AKT pathway in breast cancer. PI3K/AKT signalling regulates a number of downstream mitogenic pathways in breast cancer, and tumours with PI3K (PIK3CA) mutations often express high levels of AR (Gonzalez-Angulo et al. 2009). Breast cancer cell lines that express AR may be more sensitive to the PI3K inhibitor NVP-BEZ235 than AR-negative lines; however, only ER $\alpha$-positive AR-positive lines such as MCF7 and BT-474 demonstrated enhanced inhibitory effects of NVP-BEZ235 in the presence of DHT (Lehmann et al. 2011, Wang et al. $2013 a, b)$. This is perhaps due to the latter study reporting growth inhibitory effects rather than growth stimulatory effects of DHT in ER $\alpha$-negative AR-positive lines such as MDA-MB-453. However, combined inhibitory effects of AR antagonists and PI3K inhibition in this context have not been reported to date. This suggests that the crosstalk between ligand-dependent AR signalling and the PI3K pathway can regulate growth of breast cancer cells.

\section{AR and cell cycle regulators}

The breast cancer susceptibility gene and cell cycle regulatory protein BRCA1 has been shown to interact with the AR and synergise with the coactivator GRIP1 (NCOA2) to enhance AR activity on a transfected AR-responsive probasin reporter gene in $\mathrm{ER} \alpha$-positive MCF7 and ER $\alpha$-negative HBL-100 breast cancer cells (Park et al. 2000). Mutations in the BRCA1 protein have been shown to be associated with a lower prevalence of $A R$ immunoreactivity in breast cancer tissues (Berns et al. 2003, Pristauz et al. 2010), further suggesting a link between AR and the tumour suppressive role of BRCA1 in breast tissues. Additional evidence for AR modulation of cell cycle pathways is derived from studies demonstrating that $\mathrm{AR}$ expression is positively correlated with that of RB1 (Bieche et al. 2001). Cyclin D1 (CCND1), which controls entry into the $S$ phase of the cell cycle, is also regulated by AR; recruitment of ligand-bound $\mathrm{AR}$ in combination with the orphan nuclear receptor DAX1 to an androgen-responsive element in the CCND1 promoter results in repression of the transcription of CCND1 and subsequent inhibition of proliferation in ER $\alpha$-positive MCF7 breast cancer cells (Fig. 1D; Lanzino et al. 2010). Similarly, studies on ER $\alpha$ negative MDA-MB-231 cells stably transfected with $A R$, which are growth inhibited by androgen, indicate that antiproliferative effects are mediated through a decrease in cyclin D1 levels and an increase in the cyclin-dependent kinase (Cdk) inhibitor p21 (CDKN1A), which is required for the proliferative effects of androgen (Fig. 1D; Garay et al. 2012). Importantly, inhibition of proliferation in this model required activation of both $\mathrm{AR}$ and the EGFR/MAPK signalling pathway, whereas activation of either of these pathways alone led to increased proliferation (Garay et al. 2012). This indicates the potential importance of the MAPK pathway in mediating the proliferative effects of androgens, although this requirement for MAPK has not been studied in the context of breast cancer cells expressing endogenous AR.

\section{Intracrine androgen metabolism in the breast}

Intracrinology refers to the study of steroid hormone synthesis and metabolism within the cells or tissues where their actions are exerted and without transport of hormones through serum, a process that efficiently directs the most potent hormones to the cells that need them (Labrie 1991). In humans, the majority of biologically active androgens and oestrogens in the body are produced locally in target tissues from circulating adrenal and/or ovarian precursors. Differences in intracrine pathways could also result in individuals with similar serum androgen levels having marked differences in tissue androgen levels. This has the potential to confound interpretation of studies investigating androgens in breast cancer, especially those investigating breast cancer risk associated with circulating androgens. Furthermore, as intracrine pathways regulate levels of androgen, and therefore AR activity, within breast cancer cells, the potential for mis-interpretation also exists for studies investigating the prognostic value of AR in breast cancer or the intracellular mechanisms of AR action in breast cancer cells in vitro. It is therefore critical to elucidate the metabolic pathways that modulate intracellular levels of androgens in the breast, and how these may be dysregulated in breast cancer. A complex system of enzymes regulates androgen and oestrogen levels in breast cells (Fig. 2), and the enzymes that have been implicated in breast cancer are described below.

\section{Aromatase}

Aromatase catalyses the process of conversion of the androgen, testosterone, to the most potent oestrogen,

Published by Bioscientifica Ltd. 


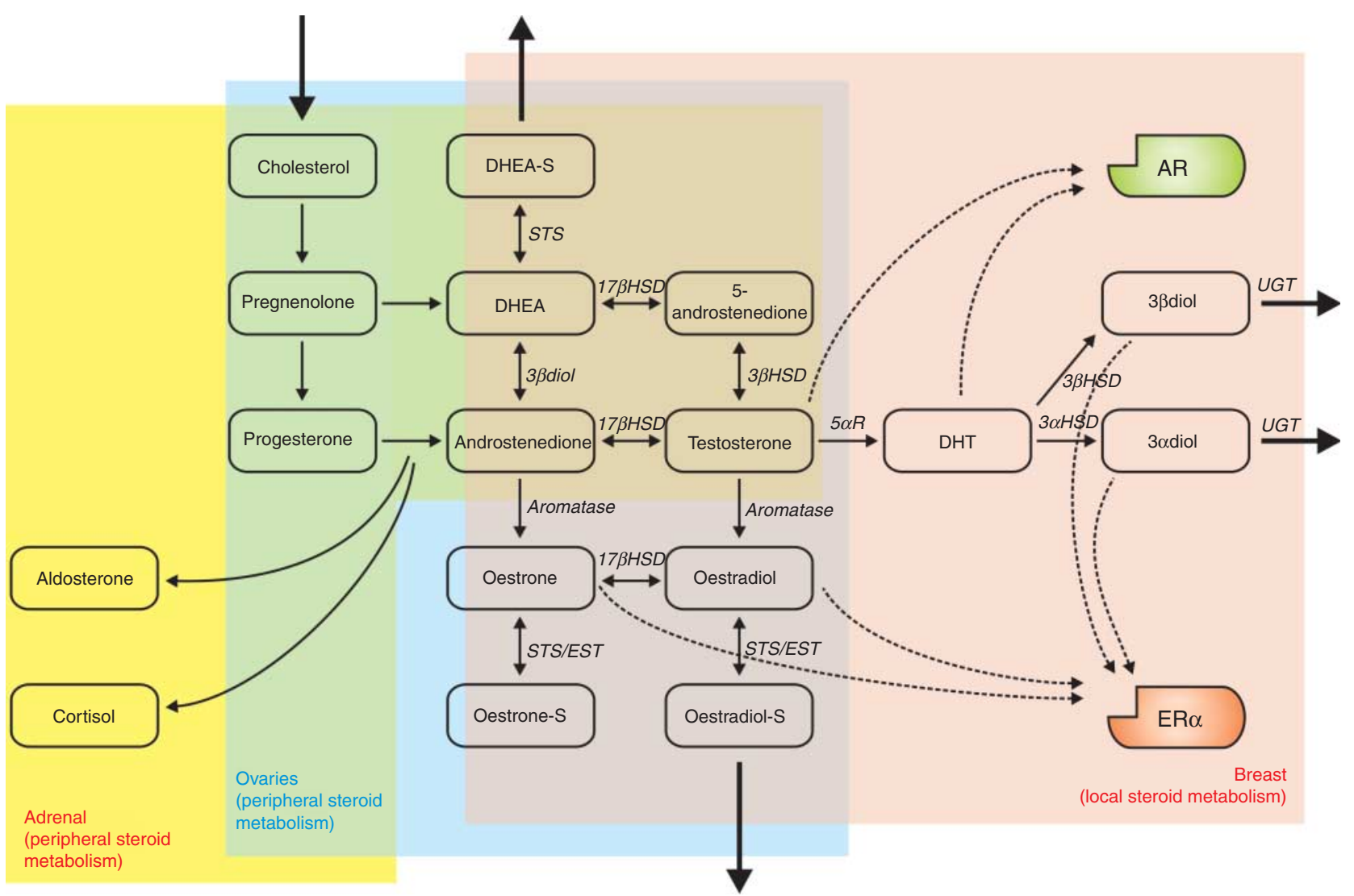

\section{Figure 2}

Predominant steroid metabolism pathways in the adrenal/ovaries and breast tissue. Enzymes are shown in italics by the relevant reaction arrow in the figure, while the binding of selected steroids to AR or ER $\alpha$ is shown by broken arrows. Bold arrows indicate points of intake or excretion of the steroids. Coloured boxes group the reactions occurring at peripheral or

$\mathrm{E}_{2}$ (Fig. 2), which generally stimulates proliferation of breast epithelial cells. This forms the basis for aromatase inhibition as a therapeutic strategy for breast cancer, which is now a standard first-line treatment regimen for postmenopausal patients with ER $\alpha$-positive disease (Santen et al. 2009, Sasano et al. 2009). While aromatase inhibition decreases $\mathrm{E}_{2}$ levels, testosterone levels increase in the breast tissue, which may contribute to the efficacy of aromatase inhibitors in ER $\alpha$-positive disease through the anti-proliferative effect of androgens (Macedo et al. 2006, Chanplakorn et al. 2011). It has been proposed that any findings of increased breast cancer risk associated with endogenous serum testosterone are largely due to conversion to $\mathrm{E}_{2}$ by aromatase in the breast (reviewed by Shufelt \& Braunstein (2008)). Therefore, in studies evaluating a potential association between serum testosterone and breast cancer risk, it is necessary to determine whether there is a direct risk from circulating testosterone, or an indirect risk from the metabolism of local sites. All enzymes are discussed in the text with the exception of oestrogen sulphotransferase (EST), which is an oestrogen-specific enzyme and hence outside the scope of this article, however, given its importance both biologically and therapeutically (reviewed by McNamara et al. (2013b)) and as such is included in this diagram.

testosterone to $\mathrm{E}_{2}$ by aromatase. As shown in Table 1 , several studies have addressed this and some found that the increased breast cancer risk associated with increased serum testosterone is ameliorated when testosterone to $\mathrm{E}_{2}$ conversion is taken into account. Although these studies only measured serum levels of hormones and not the potential for localised synthesis of $\mathrm{E}_{2}$ from circulating testosterone by aromatase in breast tissues, they do suggest that aromatase activity may be an important modifier of breast cancer risk.

Further direct interactions between androgen signalling and aromatase have been suggested at the molecular level. A recent study has described a novel mechanism where activated AR co-operates with the orphan nuclear receptor DAX1 to suppress ER $\alpha$-mediated transcription of aromatase (Lanzino et al. 2013). Additionally, the androgen-regulated microRNA Let-7a (hsa-let7a) (Lyu et al. 2014) clusters with Let-7f (hsa-let-7f), which has been shown to suppress

Published by Bioscientifica Ltd. 
aromatase in ER $\alpha$-positive MCF7 breast cancer cells (Shibahara et al. 2012). Therefore, the protective actions of androgens, at least in ER $\alpha$-positive breast cancers, may be partially achieved through down-regulation of aromatase and decreased intracrine synthesis of oestrogens.

\section{$5 \alpha$ reductase family}

$5 \alpha$ reductase $(5 \alpha \mathrm{R})$ enzymes catalyse the conversion of testosterone to DHT (Fig. 2). This prevents $\mathrm{E}_{2}$ synthesis, as DHT is not a substrate for aromatase, and acts as an amplification of the androgen signal due to the higher affinity of DHT compared with testosterone for the AR. Of the three known isoforms, $5 \alpha \mathrm{R} 1$ is expressed more frequently in the breast than $5 \alpha \mathrm{R} 2$ and is considered the principal isoform (Suzuki et al. 2001) despite its lower affinity for testosterone (Jin \& Penning 2006), while $5 \alpha$ R3 has not been reported in the breast. The importance of $5 \alpha \mathrm{R} 1$ in breast cancer development remains unclear, as either higher (Lewis et al. 2004) or lower (Zhao et al. 2010) levels of $5 \alpha \mathrm{R} 1$ have been reported in tumour compared with matched normal tissues. However, a large number of studies suggest an inhibitory role for $5 \alpha \mathrm{R} 1$ in disease progression. In invasive ductal carcinoma, $5 \alpha \mathrm{R} 1$ expression is inversely correlated with tumour grade and proliferative index (Suzuki et al. 2006, McNamara et al. 2013a), decreased in invasive carcinomas compared with organ-confined disease (Shibuya et al. 2008, McNamara et al. 2014) and decreased in metastatic lymph nodes compared with primary tumours (Shibahara et al. 2013). Additionally, tumours positive for both AR and $5 \alpha \mathrm{R} 1$ are smaller in size, exhibit reduced Ki67 proliferative index and are associated with longer disease-free and overall survival compared with tumours that express either one or neither of these markers (Suzuki et al. 2006, McNamara et al. 2013a, 2014). 5aR1 has also been shown to be up-regulated by androgen treatment in the MDA-MB-453 breast cancer cell line, suggesting a mechanistic relationship between AR and 5aR1 (McNamara et al. 2014). Importantly, this suggests that expression of androgenmetabolising enzymes can strengthen the prognostic value of AR, particularly in TNBCs that do not exhibit a clear association between AR and clinical outcome (see section 'Triple negative breast cancer'). This effect on prognosis may be due to androgen regulation of steroid intracrinology, indicating the need for a better understanding of androgen intracrinology to better define the role of $\mathrm{AR}$ in breast tumourigenesis.

Polymorphisms in the $5 \alpha R 2$ gene that decrease enzyme activity, and therefore reduce DHT levels, are associated with an increased breast cancer risk (Francis et al. 2014) and/or shorter survival (Bharaj et al. 2000, Scorilas et al. 2001), although significant harmful effects of these alleles have not been consistently reported (Spurdle et al. 2001, Yang et al. 2002, van Gils et al. 2003). Increased levels of $5 \alpha \mathrm{R} 2$, but not $5 \alpha \mathrm{R} 1$, were detected in $\mathrm{ER} \alpha$-positive breast tumours in which the proliferation index decreased by more than $40 \%$ following aromatase inhibitor therapy (Chanplakorn et al. 2011). These studies suggest that while $5 \alpha \mathrm{R} 2$ may not be the predominant isoform, it nevertheless may play an important protective role in breast cancer in addition to $5 \alpha \mathrm{R} 1$.

\section{7ß-hydroxysteroid dehydrogenase type 5 family}

$17 \beta$-hydroxysteroid dehydrogenases (17 $\beta$ HSDs) catalyse many reactions, including the reversible conversions between $\mathrm{A}_{4}$ and testosterone and between $\mathrm{E}_{1}$ and $\mathrm{E}_{2}$ (Fig. 2), thus controlling the balance between the potent steroids testosterone and $\mathrm{E}_{2}$, and their less potent counterparts $\mathrm{A}_{4}$ and $\mathrm{E}_{1}$. The principal $17 \beta \mathrm{HSD}$ enzyme studied with regard to androgen action in breast tissues is 17ßHSD5 (AKR1C3), which catalyses the conversion between $\mathrm{A}_{4}$ and testosterone (Dufort et al. 1999, Nagasaki et al. 2009, Suzuki et al. 2010). At present, 17ßHSD5 expression in cancer as opposed to normal tissues is uncertain, with some studies suggesting a decrease and others an increase in cancer compared with normal tissues (Vihko et al. 2005, Han et al. 2008, Byrns \& Penning 2009). Correlations between $17 \beta$ HSD5 expression and other clinico-pathological markers such as age, stage and tumour size have not been observed (Suzuki et al. 2005, Han et al. 2008, McNamara et al. 2013a). However, expression of 17ßHSD5 does correlate with that of $5 \alpha \mathrm{R} 1$ and $\mathrm{AR}$ in both ER $\alpha$-positive and TNBCs (Suzuki et al. 2001, McNamara et al. 2013a, 2014) and is lost in lymph node metastasis in ER $\alpha$-positive breast cancers (Shibahara et al. 2013) and between DCIS and IDC in triple-negative cancers (McNamara et al. 2014). In interpreting the significance of 17ßHSD5 expression and androgen metabolism in breast epithelial cells, a confounding factor is that substrates for $17 \beta \mathrm{HSD}$ enzymes are not limited to androgenic steroids; other substrates include prostaglandin and progesterone (Byrns \& Penning 2009, Byrns et al. 2010). Consequently, it is necessary to determine both enzyme and substrate levels in breast tissue to accurately assess the importance of $17 \beta \mathrm{HSD} 5$ activity in testosterone metabolism. However, co-expression of 17ßHSD5 with other androgen biosynthetic enzymes in precursor lesions and breast cancers suggests that it is probably an important factor in the regulation of androgen action in this disease.

Published by Bioscientifica Ltd. 


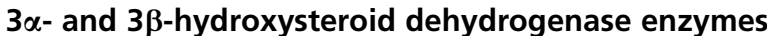

The potent androgen DHT is metabolised by $3 \alpha-$ and $3 \beta$-hydroxysteroid dehydrogenase enzymes ( $3 \alpha \mathrm{HSD}$ and $3 \beta \mathrm{HSD}$ ) to $3 \alpha$-diol and $3 \beta$-diol respectively (Fig. 2). While little is known about the expression of these enzymes in breast cancer, $3 \alpha \mathrm{HSD} 2$ is expressed in the mammary gland

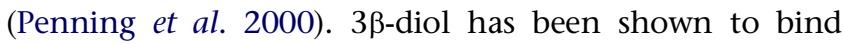
$\mathrm{ER} \alpha$ and stimulate proliferation in ER $\alpha$-positive T-47D and ZR-75-1 breast cancer cell lines (Chen et al. 2013), demonstrating that these androgen metabolites can have weak oestrogenic properties, thus enhancing ER $\alpha$ function while decreasing AR activity through metabolism of DHT. In breast cancer tissues, presence of the most potent oestrogen, $\mathrm{E}_{2}$, may minimise the biological relevance of these weakly oestrogenic metabolites to breast cancer biology (Honma et al. 2011). However, in an oestrogen-deplete environment, such as in postmenopausal women or women undergoing aromatase inhibitor therapy, $3 \alpha$-diol and $3 \beta$-diol may exert a proliferative effect on breast epithelial cells.

\section{Steroid sulphatase and UDP glucuronosyltransferase enzymes}

Comparatively, few studies have investigated the role of steroid-deconjugating or -conjugating enzymes such as steroid sulphatase (STS) or UDP glucuronosyltransferase (UGT) in relation to androgens in breast cancer. STS acts on substrates such as DHEAS, oestradiol-S and oestrone-S, deconjugating the sulphate group from the steroid backbone and thus generating more potent steroid derivatives (Fig. 2). The localised production of active androgens from DHEAS is particularly relevant in postmenopausal women, in whom the majority of serum steroids derived from the adrenals are circulating in a hydrophilic sulphated form. To date, the role of STS in breast cancer has been investigated more in relation to the production of oestrogens rather than androgens (reviewed by McNamara et al. (2013b)). An increase in the levels of STS has been shown to be associated with poor outcomes in breast cancer (Utsumi et al. 1999, Suzuki et al. 2003, Chanplakorn et al. 2010), suggesting that inhibition of this enzyme is a potential therapeutic strategy (Geisler et al. 2011). Indeed, increased STS enzyme activity is postulated as a potential mechanism for the failure of endocrine therapy for breast cancer due to an associated increase in oestrogen levels (Chanplakorn et al. 2010). Whether or not expression of STS in breast cancers alters androgen levels is not known. Similarly, little is known about the androgenconjugating UGT enzyme family that glucuronidates and inactivates lipophilic compounds, including androgens and oestrogens (Fig. 2). UGT enzymes are expressed in the breast (reviewed by Mackenzie et al. (2010)) and have been shown to be induced by androgens in MCF7 and MDA-MB-453 breast cancer cell lines (Harrington et al. 2006, Moore et al. 2012). There is evidence that a variant allele $\left((\mathrm{TA})_{7} /(\mathrm{TA})_{7}\right)$ of the UGT family member, UGT1A1, is associated with a reduced risk of ER $\alpha$-negative breast cancer compared with ER $\alpha$-positive breast cancer (Sparks et al. 2004). In addition, reduced expression of UGT2B7, UGT2B10 and UGT2B11 is observed in highly dense normal breast tissues, an established breast cancer risk factor, compared with less-dense tissues (Haakensen et al. 2010), suggesting that these enzymes can potentially contribute to breast tumourigenesis. However, whether or not changes in UGT affect breast tissue due to alterations in serum or tissue androgen or oestrogen levels is unknown. The inactivation/catabolism of androgens is an important but understudied aspect of androgen action in the breast.

\section{Conclusion/future directions}

There is ample evidence that androgens and the AR signalling pathway are attractive therapeutic targets for breast cancer. While AR agonists such as testosterone propionate and fluoxymesterone acetate were used successfully to treat breast cancer until the 1980s, AR antagonists are now being investigated as potential new therapies. However, a better understanding of AR action in different breast cancer subtypes is still required to effectively exploit this pathway for clinical benefit. Current clinical trials investigating AR antagonism in breast cancer patients have focused on ER $\alpha$-negative AR-positive disease, but trials are now being proposed for $E R \alpha$-positive breast cancer, where the role of $A R$ is probably quite different. Identification of appropriate markers of AR responsiveness in different breast cancer contexts is essential to better select patients who will benefit most from AR antagonist therapies. Additionally, there has been little consideration to date regarding the use of selective AR modulators (SARMs) as therapeutic agents to selectively activate AR signalling in ER $\alpha$-positive disease without the masculinising side effects associated with traditional AR agonist therapies. Recent results from a phase II clinical trial of the SARM enobosarm (NCT01616758) demonstrate the clinical benefit in six out of 17 postmenopausal women with ER $\alpha$-positive metastatic breast cancer, suggesting that this is a promising new therapeutic approach (Overmoyer et al. 2014).

Published by Bioscientifica Ltd. 
Given the predominant inhibitory role of androgen signalling in ER $\alpha$-positive breast cancer, this approach may be more successful. Again, the biomarkers of the response will be critical for patient selection.

In addition to the agents directly targeting the $\mathrm{AR}$, there is potential for the manipulation of other components of the AR signalling pathway to modulate the effects of androgens in breast cancer. While detailed molecular mechanisms of AR action in the breast are still being elucidated, it is apparent that AR interacts with several critical signalling pathways implicated in breast carcinogenesis. Therapeutic strategies indirectly targeting AR by modulating interacting factors, such as androgenmetabolising enzymes, the FOXA1 pioneer factor or cell cycle regulators, are either in use (e.g. the $5 \alpha \mathrm{R}$ inhibitor finasteride or the CYP17A1 inhibitor abiraterone acetate) or under pre-clinical investigation (e.g. Cdk inhibitors) in prostate cancer, and similar approaches may prove clinically useful in breast cancer. In fact, trials for abiraterone acetate (e.g. NCT01842321, NCT00755885 and NCT01381874), which suppresses androgen production, and Cdk inhibitors (e.g. NCT01864746 and NCT01624441) are in progress for breast cancer. Recent results have indicated that addition of abiraterone acetate to the aromatase inhibitor exemestane did not improve the outcome for postmenopausal patients with ER $\alpha$ positive breast cancer (O'Shaughnessy et al. 2014, trial NCT01381874), suggesting that inhibition of AR signalling is not a suitable approach in this disease subtype. However, abiraterone therapy may be more beneficial for women with ER $\alpha$-negative breast cancer, which is also currently under investigation (NCT01842321 and NCT00755885). While it is interesting to use information from studies on other hormone-dependent cancers, such as prostate cancer, as a potential indication of AR-interacting proteins in the breast, it is also important to remember that these pathways are potentially disease state specific and/or influenced by other therapies in vivo.

Finally, although this review has focused on the actions of AR in breast cancer, we do not fully understand the role of AR in normal breast tissue, either developmentally or with regard to changes associated with menstrual cycles, pregnancy and lactation. In primates, AR is expressed in all stages of mammary development except for late pregnancy and lactation and appears to show small, non-significant variation across the menstrual cycle (Cheng et al. 2005). Ar knockout transgenic models generally indicate that AR is required for normal mammary gland development (reviewed by Hickey et al. (2012), Chang et al. (2013) and Tarulli et al. (2014)). In the human,
AR appears to have a protective role in normal breast at least in part by opposing $\mathrm{ER} \alpha$ action (Dimitrakakis et al. 2003, Eigeliene et al. 2012, Ochnik et al. 2014). This raises the possibility of SARMs being used for breast cancer chemoprevention strategies in women with a high breast cancer risk. In support of this, a recent study has reported that AR expression, along with ER $\alpha$ and vitamin D receptor, forms a signature to classify normal breast cells and co-expression of these three receptors can also predict better breast cancer outcome (Santagata et al. 2014).

In conclusion, androgen and AR actions are highly complex in breast cancer. Their role in the disease varies depending on the expression of $\mathrm{ER} \alpha$ and other interacting pathways. As inhibitory therapies targeting AR have been established for prostate cancer, AR is an attractive 'lowhanging fruit' in the treatment of breast cancer. However, refining selection criteria and determining 'in whom' and 'to do what' will be essential in the effective clinical utilisation of agents that either specifically inhibit or selectively activate AR to improve the breast cancer outcomes.

\section{Supplementary data}

This is linked to the online version of the paper at http://dx.doi.org/10.1530/ ERC-14-0243.

Declaration of interest

The authors declare that there is no conflict of interest that could be perceived as prejudicing the impartiality of the review.

\section{Funding}

This work was funded by grants from the National Health and Medical Research Council of Australia (ID 1008349 to W D Tilley), Cancer Australia (ID 1043491 to W D Tilley, T E Hickey and N L Moore), the National Breast Cancer Foundation of Australia (ID NC-08-12 to T E Hickey and NC-12-21 to N L Moore) and Susan G Komen for the Cure (ID BCTR0601118 and BCTR0504475 to W D Tilley). T E Hickey holds a Postdoctoral Fellowship Award from the U.S. Department of Defense Breast Cancer Research Program (W81XWH-11-1-0592) and K M McNamara was supported for part of this work by an Australian Academy of Science/Japan Society for the Promotion of Science postdoctoral fellowship.

\section{Author contribution statement}

K M McNamara and N L Moore wrote and prepared the manuscript and prepared the figures and tables. T E Hickey, H Sasano and W D Tilley contributed to manuscript editing and critical review.

\section{Acknowledgements}

The authors wish to thank Dr Gerard Tarulli for helpful discussions regarding the manuscript. 


\section{References}

Adly L, Hill D, Sherman ME, Sturgeon SR, Fears T, Mies C, Ziegler RG, Hoover RN \& Schairer C 2006 Serum concentrations of estrogens, sex hormone-binding globulin, and androgens and risk of breast cancer in postmenopausal women. International Journal of Cancer 119 2402-2407. (doi:10.1002/ijc.22203)

Agoff SN, Swanson PE, Linden H, Hawes SE \& Lawton TJ 2003 Androgen receptor expression in estrogen receptor-negative breast cancer. Immunohistochemical, clinical, and prognostic associations. American Journal of Clinical Pathology 120 725-731. (doi:10.1309/42F00D0DJD0J5EDT)

Agrawal AK, Jelen M, Grzebieniak Z, Zukrowski P, Rudnicki J \& Nienartowicz E 2008 Androgen receptors as a prognostic and predictive factor in breast cancer. Folia Histochemica et Cytobiologica 46 269-276. (doi:10.2478/v10042-008-0039-y)

Allegra JC, Lippman ME, Simon R, Thompson EB, Barlock A, Green L, Huff KK, Do HM, Aitken SC \& Warren R 1979 Association between steroid hormone receptor status and disease-free interval in breast cancer. Cancer Treatment Reports 63 1271-1277.

Ando S, De Amicis F, Rago V, Carpino A, Maggiolini M, Panno ML \& Lanzino M 2002 Breast cancer: from estrogen to androgen receptor. Molecular and Cellular Endocrinology 193 121-128. (doi:10.1016/ S0303-7207(02)00105-3)

Asscheman H, Giltay EJ, Megens JA, de Ronde WP, van Trotsenburg MA \& Gooren LJ 2011 A long-term follow-up study of mortality in transsexuals receiving treatment with cross-sex hormones. European Journal of Endocrinology 164 635-642. (doi:10.1530/EJE-10-1038)

Augello MA, Hickey TE \& Knudsen KE 2011 FOXA1: master of steroid receptor function in cancer. EMBO Journal 30 3885-3894. (doi:10.1038/ emboj.2011.340)

Badve S, Dabbs DJ, Schnitt SJ, Baehner FL, Decker T, Eusebi V, Fox SB, Ichihara S, Jacquemier J, Lakhani SR et al. 2011 Basal-like and triplenegative breast cancers: a critical review with an emphasis on the implications for pathologists and oncologists. Modern Pathology 24 157-167. (doi:10.1038/modpathol.2010.200)

Baglietto L, Severi G, English DR, Krishnan K, Hopper JL, McLean C, Morris HA, Tilley WD \& Giles GG 2010 Circulating steroid hormone levels and risk of breast cancer for postmenopausal women. Cancer Epidemiology, Biomarkers \& Prevention 19 492-502. (doi:10.1158/10559965.EPI-09-0532)

Barcellos-Hoff MH 2013 Does microenvironment contribute to the etiology of estrogen receptor-negative breast cancer? Clinical Cancer Research 19 541-548. (doi:10.1158/1078-0432.CCR-12-2241)

Bentz EK, Pils D, Bilban M, Kaufmann U, Hefler LA, Reinthaller A, Singer CF, Huber JC, Horvat R \& Tempfer CB 2010 Gene expression signatures of breast tissue before and after cross-sex hormone therapy in femaleto-male transsexuals. Fertility and Sterility 94 2688-2696. (doi:10.1016/j. fertnstert.2010.04.024)

Berns EM, Dirkzwager-Kiel MJ, Kuenen-Boumeester V, Timmermans M, Verhoog LC, van den Ouweland AM, Meijer-Heijboer H, Klijn JG \& van der Kwast TH 2003 Androgen pathway dysregulation in BRCA1mutated breast tumors. Breast Cancer Research and Treatment 79 121-127. (doi:10.1023/A:1023347409599)

Berrino F, Pasanisi P, Bellati C, Venturelli E, Krogh V, Mastroianni A, Berselli E, Muti P \& Secreto G 2005 Serum testosterone levels and breast cancer recurrence. International Journal of Cancer 113 499-502. (doi:10.1002/ijc.20582)

Bharaj B, Scorilas A, Giai M \& Diamandis EP 2000 TA repeat polymorphism of the $5 \alpha$-reductase gene and breast cancer. Cancer Epidemiology, Biomarkers \& Prevention 9 387-393.

Bieche I, Parfait B, Tozlu S, Lidereau R \& Vidaud M 2001 Quantitation of androgen receptor gene expression in sporadic breast tumors by real-time RT-PCR: evidence that MYC is an AR-regulated gene. Carcinogenesis 22 1521-1526. (doi:10.1093/carcin/22.9.1521)

Birrell SN, Bentel JM, Hickey TE, Ricciardelli C, Weger MA, Horsfall DJ \& Tilley WD 1995 Androgens induce divergent proliferative responses in human breast cancer cell lines. Journal of Steroid Biochemistry and Molecular Biology 52 459-467. (doi:10.1016/0960-0760(95)00005-K)

Braunstein GD 2007 Safety of testosterone treatment in postmenopausal women. Fertility and Sterility $\mathbf{8 8} 1-17$. (doi:10.1016/j.fertnstert. 2007.01.118)

Braunstein GD, Reitz RE, Buch A, Schnell D \& Caulfield MP 2011 Testosterone reference ranges in normally cycling healthy premenopausal women. Journal of Sexual Medicine 8 2924-2934. (doi:10.1111/j. 1743-6109.2011.02380.x)

Bryan RM, Mercer RJ, Bennett RC, Rennie GC, Lie TH \& Morgan FJ 1984 Androgen receptors in breast cancer. Cancer 54 2436-2440. (doi:10. 1002/1097-0142(19841201)54:11 <2436::AID-CNCR2820541121> 3.0.CO;2-H)

Bui HN, Sluss PM, Blincko S, Knol DL, Blankenstein MA \& Heijboer AC 2013 Dynamics of serum testosterone during the menstrual cycle evaluated by daily measurements with an ID-LC-MS/MS method and a 2nd generation automated immunoassay. Steroids 78 96-101. (doi:10.1016/j.steroids.2012.10.010)

Burger HG 2002 Androgen production in women. Fertility and Sterility 77 (Suppl 4) S3-S5. (doi:10.1016/S0015-0282(02)02985-0)

Burgess HE \& Shousha S 1993 An immunohistochemical study of the longterm effects of androgen administration on female-to-male transsexual breast: a comparison with normal female breast and male breast showing gynaecomastia. Journal of Pathology 170 37-43. (doi:10.1002/ path.1711700107)

Byrns MC \& Penning TM 2009 Type 5 17 $\beta$-hydroxysteroid dehydrogenase/prostaglandin F synthase (AKR1C3): role in breast cancer and inhibition by non-steroidal anti-inflammatory drug analogs. ChemicoBiological Interactions 178 221-227. (doi:10.1016/j.cbi.2008.10.024)

Byrns MC, Duan L, Lee SH, Blair IA \& Penning TM 2010 Aldo-keto reductase $1 \mathrm{C} 3$ expression in MCF-7 cells reveals roles in steroid hormone and prostaglandin metabolism that may explain its over-expression in breast cancer. Journal of Steroid Biochemistry and Molecular Biology 118 177-187. (doi:10.1016/j.jsbmb.2009.12.009)

Cancer Genome Atlas N 2012 Comprehensive molecular portraits of human breast tumours. Nature 490 61-70. (doi:10.1038/nature11412)

Carreno G, Del Casar JM, Corte MD, Gonzalez LO, Bongera M, Merino AM, Juan G, Obregon R, Martinez E \& Vizoso FJ 2007 Local recurrence after mastectomy for breast cancer: analysis of clinicopathological, biological and prognostic characteristics. Breast Cancer Research and Treatment 102 61-73. (doi:10.1007/s10549-006-9310-0)

Castellano I, Allia E, Accortanzo V, Vandone AM, Chiusa L, Arisio R, Durando A, Donadio M, Bussolati G, Coates AS et al. 2010 Androgen receptor expression is a significant prognostic factor in estrogen receptor positive breast cancers. Breast Cancer Research and Treatment 124 607-617. (doi:10.1007/s10549-010-0761-y)

Castellano I, Chiusa L, Vandone AM, Beatrice S, Goia M, Donadio M, Arisio R, Muscara F, Durando A, Viale G et al. 2013 A simple and reproducible prognostic index in luminal ER-positive breast cancers. Annals of Oncology 24 2292-2297. (doi:10.1093/annonc/mdt183)

Chang C, Lee SO, Wang RS, Yeh S \& Chang TM 2013 Androgen receptor (AR) physiological roles in male and female reproductive systems: lessons learned from AR-knockout mice lacking AR in selective cells. Biology of Reproduction 89 21. (doi:10.1095/biolreprod.113.109132)

Chanplakorn N, Chanplakorn P, Suzuki T, Ono K, Chan MS, Miki Y, Saji S, Ueno T, Toi M \& Sasano H 2010 Increased estrogen sulfatase (STS) and $17 \beta$-hydroxysteroid dehydrogenase type 1(17 $\beta$-HSD1) following neoadjuvant aromatase inhibitor therapy in breast cancer patients. Breast Cancer Research and Treatment 120 639-648. (doi:10.1007/ s10549-010-0785-3)

Chanplakorn N, Chanplakorn P, Suzuki T, Ono K, Wang L, Chan MS, Wing L, Yiu CC, Chow LW \& Sasano H 2011 Increased $5 \alpha$-reductase type 2 expression in human breast carcinoma following aromatase inhibitor therapy: the correlation with decreased tumor cell proliferation. Hormones \& Cancer 2 73-81. (doi:10.1007/s12672-010-0062-2) 
Chen J, Wang WQ \& Lin SX 2013 Interaction of androst-5-ene-3 $\beta, 17 \beta$-diol and $5 \alpha$-androstane- $3 \beta, 17 \beta$-diol with estrogen and androgen receptors: a combined binding and cell study. Journal of Steroid Biochemistry and Molecular Biology 137 316-321. (doi:10.1016/j.jsbmb.2013.01.012)

Cheng G, Li Y, Omoto Y, Wang Y, Berg T, Nord M, Vihko P, Warner M, । kern-2ptPiao YS \& Gustafsson JA 2005 Differential regulation of estrogen receptor (ER) $\alpha$ and ER $\beta$ in primate mammary gland. Journal of Clinical Endocrinology and Metabolism 90 435-444. (doi:10.1210/jc. 2004-0861)

Chia KM, Liu J, Francis GD \& Naderi A 2011 A feedback loop between androgen receptor and ERK signaling in estrogen receptor-negative breast cancer. Neoplasia 13 154-166.

Chintamani, Kulshreshtha P, Chakraborty A, Singh L, Mishra AK, Bhatnagar D \& Saxena S 2010 Androgen receptor status predicts response to chemotherapy, not risk of breast cancer in Indian women. World Journal of Surgical Oncology 8 64. (doi:10.1186/1477-7819-8-64)

Cleator S, Heller W \& Coombes RC 2007 Triple-negative breast cancer: therapeutic options. Lancet Oncology 8 235-244. (doi:10.1016/S14702045(07)70074-8)

Cochrane DR, Bernales S, Jacobsen BM, Cittelly DM, Howe EN, D Amato NC, Spoelstra NS, Edgerton SM, Jean A, Guerrero J et al. 2014 Role of the androgen receptor in breast cancer and preclinical analysis of enzalutamide. Breast Cancer Research 16 R7. (doi:10.1186/bcr3599)

Collins LC, Cole KS, Marotti JD, Hu R, Schnitt SJ \& Tamimi RM 2011 Androgen receptor expression in breast cancer in relation to molecular phenotype: results from the Nurses' Health Study. Modern Pathology 24 924-931. (doi:10.1038/modpathol.2011.54)

Cops EJ, Bianco-Miotto T, Moore NL, Clarke CL, Birrell SN, Butler LM \& Tilley WD 2008 Antiproliferative actions of the synthetic androgen, mibolerone, in breast cancer cells are mediated by both androgen and progesterone receptors. Journal of Steroid Biochemistry and Molecular Biology 110 236-243. (doi:10.1016/j.jsbmb.2007.10.014)

Curtis C, Shah SP, Chin SF, Turashvili G, Rueda OM, Dunning MJ, Speed D, Lynch AG, Samarajiwa S, Yuan Y et al. 2012 The genomic and transcriptomic architecture of 2,000 breast tumours reveals novel subgroups. Nature 486 346-352. (doi:10.1038/nature10983)

Davis SR 2010 Should women receive androgen replacement therapy, and if so, how? Clinical Endocrinology 72 149-154. (doi:10.1111/j.13652265.2009.03670.x)

De Amicis F, Thirugnansampanthan J, Cui Y, Selever J, Beyer A, Parra I, Weigel NL, Herynk MH, Tsimelzon A, Lewis MT et al. 2010 Androgen receptor overexpression induces tamoxifen resistance in human breast cancer cells. Breast Cancer Research and Treatment 121 1-11. (doi:10.1007/s10549-009-0436-8)

Dimitrakakis C, Zhou J, Wang J, Belanger A, LaBrie F, Cheng C, Powell D \& Bondy C 2003 A physiologic role for testosterone in limiting estrogenic stimulation of the breast. Menopause 10 292-298. (doi:10.1097/01. GME.0000055522.67459.89)

Doane AS, Danso M, Lal P, Donaton M, Zhang L, Hudis C \& Gerald WL 2006 An estrogen receptor-negative breast cancer subset characterized by a hormonally regulated transcriptional program and response to androgen. Oncogene 25 3994-4008. (doi:10.1038/sj.onc.1209415)

Dorgan JF, Stanczyk FZ, Kahle LL \& Brinton LA 2010 Prospective case-control study of premenopausal serum estradiol and testosterone levels and breast cancer risk. Breast Cancer Research 12 R98. (doi:10.1186/bcr2779)

Dufort I, Rheault P, Huang XF, Soucy P \& Luu-The V 1999 Characteristics of a highly labile human type $517 \beta$-hydroxysteroid dehydrogenase. Endocrinology 140 568-574.

Eigeliene N, Elo T, Linhala M, Hurme S, Erkkola R \& Härkönen P 2012 Androgens inhibit the stimulatory action of $17 \beta$-estradiol on normal human breast tissue in explant cultures. Journal of Clinical Endocrinology and Metabolism 97 E1116-E1127. (doi:10.1210/jc.2011-3228)

Eliassen AH, Missmer SA, Tworoger SS, Spiegelman D, Barbieri RL, Dowsett M $\&$ Hankinson SE 2006 Endogenous steroid hormone concentrations and risk of breast cancer among premenopausal women. Journal of the National Cancer Institute 98 1406-1415. (doi:10.1093/jnci/djj376)

Farhat GN, Cummings SR, Chlebowski RT, Parimi N, Cauley JA, Rohan TE, Huang AJ, Vitolins M, Hubbell FA, Manson JE et al. 2011 Sex hormone levels and risks of estrogen receptor-negative and estrogen receptorpositive breast cancers. Journal of the National Cancer Institute 103 562-570. (doi:10.1093/jnci/djr031)

Farmer P, Bonnefoi H, Becette V, Tubiana-Hulin M, Fumoleau P, Larsimont D, Macgrogan G, Bergh J, Cameron D, Goldstein D et al. 2005 Identification of molecular apocrine breast tumours by microarray analysis. Oncogene 24 4660-4671. (doi:10.1038/sj.onc.1208561)

Fourkala EO, Zaikin A, Burnell M, Gentry-Maharaj A, Ford J, Gunu R, Soromani C, Hasenbrink G, Jacobs I, Dawnay A et al. 2012 Association of serum sex steroid receptor bioactivity and sex steroid hormones with breast cancer risk in postmenopausal women. Endocrine-Related Cancer 19 137-147. (doi:10.1530/ERC-11-0310)

Francis A, Sarkar S, Pooja S, Surekha D, Rao DR, Rao L, Ramachandra L, Vishnupriya S, Satyamoorthy K, Thangaraj K et al. 2014 SRD5A2 gene polymorphisms affect the risk of breast cancer. Breast 2 137-141. (doi:10.1016/j.breast.2013.11.010)

Garay JP, Karakas B, Abukhdeir AM, Cosgrove DP, Gustin JP, Higgins MJ, Konishi H, Konishi Y, Lauring J, Mohseni M et al. 2012 The growth response to androgen receptor signaling in $\mathrm{ER} \alpha$-negative human breast cells is dependent on p21 and mediated by MAPK activation. Breast Cancer Research 14 R27. (doi:10.1186/bcr3112)

Geisler J, Sasano H, Chen S \& Purohit A 2011 Steroid sulfatase inhibitors: promising new tools for breast cancer therapy? Journal of Steroid Biochemistry and Molecular Biology 125 39-45. (doi:10.1016/j.jsbmb. 2011.02.002)

van Gils CH, Onland-Moret NC, Roest M, van Noord PA \& Peeters PH 2003 The V89L polymorphism in the 5 - $\alpha$-reductase type 2 gene and risk of breast cancer. Cancer Epidemiology, Biomarkers \& Prevention 12 1194-1199.

Gonzalez LO, Corte MD, Vazquez J, Junquera S, Sanchez R, Alvarez AC, Rodriguez JC, Lamelas ML \& Vizoso FJ 2008 Androgen receptor expression in breast cancer: relationship with clinicopathological characteristics of the tumors, prognosis, and expression of metalloproteases and their inhibitors. BMC Cancer 8 149. (doi:10.1186/14712407-8-149)

Gonzalez-Angulo AM, Stemke-Hale K, Palla SL, Carey M, Agarwal R, MericBerstam F, Traina TA, Hudis C, Hortobagyi GN, Gerald WL et al. 2009 Androgen receptor levels and association with PIK3CA mutations and prognosis in breast cancer. Clinical Cancer Research 15 2472-2478. (doi:10.1158/1078-0432.CCR-08-1763)

Gucalp A, Tolaney S, Isakoff SJ, Ingle JN, Liu MC, Carey LA, Blackwell K, Rugo H, Nabell L, Forero A et al. 2013 Phase II trial of bicalutamide in patients with androgen receptor-positive, estrogen receptor-negative metastatic breast cancer. Clinical Cancer Research 19 5505-5512. (doi:10.1158/1078-0432.CCR-12-3327)

Haakensen VD, Biong M, Lingjærde OC, Holmen MM, Frantzen JO, Chen Y, Navjord D, Romundstad L, Lüders T, Bukholm IK et al. 2010 Expression levels of uridine 5'-diphospho-glucuronosyltransferase genes in breast tissue from healthy women are associated with mammographic density. Breast Cancer Research 12 R65. (doi:10.1186/ bcr2632)

Hackenberg R, Hofmann J, Holzel F \& Schulz KD 1988 Stimulatory effects of androgen and antiandrogen on the in vitro proliferation of human mammary carcinoma cells. Journal of Cancer Research and Clinical Oncology 114 593-601. (doi:10.1007/BF00398183)

Hackenberg R, Luttchens S, Hofmann J, Kunzmann R, Holzel F \& Schulz KD 1991 Androgen sensitivity of the new human breast cancer cell line MFM-223. Cancer Research 51 5722-5727.

Hackenberg R, Hawighorst T, Filmer A, Nia AH \& Schulz KD 1993 Medroxyprogesterone acetate inhibits the proliferation of estrogenand progesterone-receptor negative MFM-223 human mammary 
cancer cells via the androgen receptor. Breast Cancer Research and Treatment 25 217-224. (doi:10.1007/BF00689836)

Hall RE, Birrell SN, Tilley WD \& Sutherland RL 1994 MDA-MB-453, an androgen-responsive human breast carcinoma cell line with high level androgen receptor expression. European Journal of Cancer 30A 484-490. (doi:10.1016/0959-8049(94)90424-3)

Hammond ME, Hayes DF, Dowsett M, Allred DC, Hagerty KL, Badve S, Fitzgibbons PL, Francis G, Goldstein NS, Hayes M et al. 2010 American Society of Clinical Oncology/College of American Pathologists guideline recommendations for immunohistochemical testing of estrogen and progesterone receptors in breast cancer (unabridged version). Archives of Pathology \& Laboratory Medicine 134 e48-e72. (doi:10.1043/ 1543-2165-134.6.907)

Han B, Li S, Song D, Poisson-Pare D, Liu G, Luu-The V, Ouellet J, Labrie F \& Pelletier G 2008 Expression of $17 \beta$-hydroxysteroid dehydrogenase type 2 and type 5 in breast cancer and adjacent non-malignant tissue: a correlation to clinicopathological parameters. Journal of Steroid Biochemistry and Molecular Biology 112 194-200. (doi:10.1016/j.jsbmb. 2008.10.004)

Hankinson SE, Willett WC, Manson JE, Colditz GA, Hunter DJ, Spiegelman D, Barbieri RL \& Speizer FE 1998 Plasma sex steroid hormone levels and risk of breast cancer in postmenopausal women. Journal of the National Cancer Institute 90 1292-1299. (doi:10.1093/jnci/90.17.1292)

Hanley K, Wang J, Bourne P, Yang Q, Gao AC, Lyman G \& Tang P 2008 Lack of expression of androgen receptor may play a critical role in transformation from in situ to invasive basal subtype of high-grade ductal carcinoma of the breast. Human Pathology 39 386-392. (doi:10.1016/j.humpath.2007.07.007)

Harrington WR, Sengupta S \& Katzenellenbogen BS 2006 Estrogen regulation of the glucuronidation enzyme UGT2B15 in estrogen receptor-positive breast cancer cells. Endocrinology 147 3843-3850. (doi:10.1210/en.2006-0358)

Harwood DT \& Handelsman DJ 2009 Development and validation of a sensitive liquid chromatography-tandem mass spectrometry assay to simultaneously measure androgens and estrogens in serum without derivatization. Clinica Chimica Acta 409 78-84. (doi:10.1016/j.cca. 2009.09.003)

He J, Peng R, Yuan Z, Wang S, Peng J, Lin G, Jiang X \& Qin T 2012 Prognostic value of androgen receptor expression in operable triple-negative breast cancer: a retrospective analysis based on a tissue microarray. Medical Oncology 29 406-410. (doi:10.1007/s12032-011-9832-0)

Hickey TE, Robinson JL, Carroll JS \& Tilley WD 2012 Minireview: the androgen receptor in breast tissues: growth inhibitor, tumor suppressor, oncogene? Molecular Endocrinology 26 1252-1267. (doi:10.1210/ me.2012-1107)

Hofling M, Hirschberg AL, Skoog L, Tani E, Hagerstrom T \& von Schoultz B 2007 Testosterone inhibits estrogen/progestogen-induced breast cell proliferation in postmenopausal women. Menopause 14 183-190. (doi:10.1097/01.gme.0000232033.92411.51)

Honma N, Saji S, Hirose M, Horiguchi SI, Kuroi K, Hayashi SI, Utsumi T \& Harada N 2011 Sex steroid hormones in pairs of tumor and serum from breast cancer patients and pathobiological role of androstene-3 $\beta, 17 \beta$-diol. Cancer Science 102 1848-1854. (doi:10.1111/j.1349-7006.2011.02018.x)

Honma N, Horii R, Iwase T, Saji S, Younes M, Ito Y \& Akiyama F 2013 Clinical importance of androgen receptor in breast cancer patients treated with adjuvant tamoxifen monotherapy. Breast Cancer 20 323-330. (doi:10.1007/s12282-012-0337-2)

Horwitz KB, Zava DT, Thilagar AK, Jensen EM \& McGuire WL 1978 Steroid receptor analyses of nine human breast cancer cell lines. Cancer Research 38 2434-2437.

Hu R, Dawood S, Holmes MD, Collins LC, Schnitt SJ, Cole K, Marotti JD, Hankinson SE, Colditz GA \& Tamimi RM 2011 Androgen receptor expression and breast cancer survival in postmenopausal women. Clinical Cancer Research 17 1867-1874. (doi:10.1158/1078-0432. CCR-10-2021)
Iggo RD 2011 New insights into the role of androgen and oestrogen receptors in molecular apocrine breast tumours. Breast Cancer Research 13 318. (doi:10.1186/bcr3036)

Ingle JN, Twito DI, Schaid DJ, Cullinan SA, Krook JE, Mailliard JA, Tschetter LK, Long HJ, Gerstner JG, Windschitl HE et al. 1991 Combination hormonal therapy with tamoxifen plus fluoxymesterone versus tamoxifen alone in postmenopausal women with metastatic breast cancer. An updated analysis. Cancer 67 886-891. (doi:10.1002/ 1097-0142(19910215)67:4<886::AID-CNCR2820670405>3.0.CO;2-O)

Jin Y \& Penning TM 2006 Multiple steps determine the overall rate of the reduction of $5 \alpha$-dihydrotestosterone catalyzed by human type 3 $3 \alpha$-hydroxysteroid dehydrogenase: implications for the elimination of androgens. Biochemistry 45 13054-13063. (doi:10.1021/bi060591r)

Kaaks R, Berrino F, Key T, Rinaldi S, Dossus L, Biessy C, Secreto G, Amiano P, Bingham S, Boeing H et al. 2005a Serum sex steroids in premenopausal women and breast cancer risk within the European Prospective Investigation into Cancer and Nutrition (EPIC). Journal of the National Cancer Institute 97 755-765. (doi:10.1093/jnci/dji132)

Kaaks R, Rinaldi S, Key TJ, Berrino F, Peeters PH, Biessy C, Dossus L, Lukanova A, Bingham S, Khaw KT et al. 2005b Postmenopausal serum androgens, oestrogens and breast cancer risk: the European prospective investigation into cancer and nutrition. Endocrine-Related Cancer 12 1071-1082. (doi:10.1677/erc.1.01038)

Kao KJ, Chang KM, Hsu HC \& Huang AT 2011 Correlation of microarraybased breast cancer molecular subtypes and clinical outcomes: implications for treatment optimization. BMC Cancer 11143. (doi:10.1186/1471-2407-11-143)

Key T, Appleby P, Barnes I \& Reeves G 2002 Endogenous sex hormones and breast cancer in postmenopausal women: reanalysis of nine prospective studies. Journal of the National Cancer Institute 94 606-616. (doi:10.1093/jnci/94.8.606)

Kollara A, Kahn HJ, Marks A \& Brown TJ 2001 Loss of androgen receptor associated protein 70 (ARA70) expression in a subset of HER2-positive breast cancers. Breast Cancer Research and Treatment 67 245-253. (doi:10.1023/A:1017938608460)

Koo JS, Jung W \& Jeong J 2009 The predictive role of E-cadherin and androgen receptor on in vitro chemosensitivity in triple-negative breast cancer. Japanese Journal of Clinical Oncology 39 560-568. (doi:10.1093/ jico/hyp065)

Krapf JM \& Simon JA 2009 The role of testosterone in the management of hypoactive sexual desire disorder in postmenopausal women. Maturitas 63 213-219. (doi:10.1016/j.maturitas.2009.04.008)

Kuenen-Boumeester V, Van der Kwast TH, van Putten WL, Claassen C, van Ooijen B \& Henzen-Logmans SC 1992 Immunohistochemical determination of androgen receptors in relation to oestrogen and progesterone receptors in female breast cancer. International Journal of Cancer 52 581-584. (doi:10.1002/ijc.2910520415)

Labrie F 1991 Intracrinology. Molecular and Cellular Endocrinology 78 C113-C118. (doi:10.1016/0303-7207(91)90116-A)

Labrie F \& Labrie C 2012 DHEA and intracrinology at menopause, a positive choice for evolution of the human species. Climacteric 16 205-213. (doi:10.3109/13697137.2012.733983)

Labrie F, Luu-The V, Labrie C, Belanger A, Simard J, Lin SX \& Pelletier G 2003 Endocrine and intracrine sources of androgens in women: inhibition of breast cancer and other roles of androgens and their precursor dehydroepiandrosterone. Endocrine Reviews 24 152-182. (doi:10.1210/er.2001-0031)

Langer M, Kubista E, Schemper M \& Spona J 1990 Androgen receptors, serum androgen levels and survival of breast cancer patients. Archives of Gynecology and Obstetrics 247 203-209. (doi:10.1007/BF02389545)

Lanzino M, De Amicis F, McPhaul MJ, Marsico S, Panno ML \& Ando S 2005 Endogenous coactivator ARA70 interacts with estrogen receptor $\alpha(\mathrm{ER} \alpha)$ and modulates the functional $\mathrm{ER} \alpha /$ androgen receptor interplay in MCF-7 cells. Journal of Biological Chemistry 280 20421-20430. (doi:10.1074/jbc.M413576200) 
Lanzino M, Sisci D, Morelli C, Garofalo C, Catalano S, Casaburi I, Capparelli C, Giordano C, Giordano F, Maggiolini M et al. 2010 Inhibition of cyclin D1 expression by androgen receptor in breast cancer cells - identification of a novel androgen response element. Nucleic Acids Research 38 5351-5365. (doi:10.1093/nar/gkq278)

Lanzino M, Maris P, Sirianni R, Barone I, Casaburi I, Chimento A, Giordano C, Morelli C, Sisci D, Rizza P et al. 2013 DAX-1, as an androgen-target gene, inhibits aromatase expression: a novel mechanism blocking estrogen-dependent breast cancer cell proliferation. Cell Death \& Disease 4 e724. (doi:10.1038/cddis.2013.235)

Lapointe J, Fournier A, Richard V \& Labrie C 1999 Androgens down-regulate bcl-2 protooncogene expression in ZR-75-1 human breast cancer cells. Endocrinology 140 416-421. (doi:10.1210/endo. 140.1.6410)

Lea OA, Kvinnsland S \& Thorsen T 1989 Improved measurement of androgen receptors in human breast cancer. Cancer Research 49 7162-7167.

Lehmann BD, Bauer JA, Chen X, Sanders ME, Chakravarthy AB, Shyr Y \& Pietenpol JA 2011 Identification of human triple-negative breast cancer subtypes and preclinical models for selection of targeted therapies. Journal of Clinical Investigation 121 2750-2767. (doi:10.1172/JCI45014)

Lehmann-Che J, Hamy AS, Porcher R, Barritault M, Bouhidel F, Habuellelah H, Leman-Detours S, de Roquancourt A, Cahen-Doidy L, Bourstyn E et al. 2013 Molecular apocrine breast cancers are aggressive estrogen receptor negative tumors overexpressing either HER2 or GCDFP15. Breast Cancer Research 15 R37. (doi:10.1186/bcr3421)

Lewis MJ, Wiebe JP \& Heathcote JG 2004 Expression of progesterone metabolizing enzyme genes (AKR1C1, AKR1C2, AKR1C3, SRD5A1, SRD5A2) is altered in human breast carcinoma. BMC Cancer 427. (doi:10.1186/1471-2407-4-27)

Loibl S, Muller BM, von Minckwitz G, Schwabe M, Roller M, Darb-Esfahani S, Ataseven B, du Bois A, Fissler-Eckhoff A, Gerber B et al. 2011 Androgen receptor expression in primary breast cancer and its predictive and prognostic value in patients treated with neoadjuvant chemotherapy. Breast Cancer Research and Treatment 130 477-487. (doi:10.1007/s10549-011-1715-8)

Luo X, Shi YX, Li ZM \& Jiang WQ 2010 Expression and clinical significance of androgen receptor in triple negative breast cancer. Chinese Journal of Cancer 29 585-590. (doi:10.5732/cjc.009.10673)

Lyu S, Yu Q, Ying G, Wang S, Wang Y, Zhang J \& Niu Y 2014 Androgen receptor decreases CMYC and KRAS expression by upregulating let-7a expression in $\mathrm{ER}-, \mathrm{PR}-, \mathrm{AR}+$ breast cancer. International Journal of Oncology 44 229-237. (doi:10.3892/ijo.2013.2151)

Macedo LF, Guo Z, Tilghman SL, Sabnis GJ, Qiu Y \& Brodie A 2006 Role of androgens on MCF-7 breast cancer cell growth and on the inhibitory effect of letrozole. Cancer Research 66 7775-7782. (doi:10.1158/00085472.CAN-05-3984)

Mackenzie PI, Hu DG \& Gardner-Stephen DA 2010 The regulation of UDPglucuronosyltransferase genes by tissue-specific and ligand-activated transcription factors. Drug Metabolism Reviews 42 99-109. (doi:10.3109/ $03602530903209544)$

Maggiolini M, Donze O, Jeannin E, Ando S \& Picard D 1999 Adrenal androgens stimulate the proliferation of breast cancer cells as direct activators of estrogen receptor $\alpha$. Cancer Research $\mathbf{5 9} 4864-4869$.

Manjer J, Johansson R, Berglund G, Janzon L, Kaaks R, Agren A \& Lenner P 2003 Postmenopausal breast cancer risk in relation to sex steroid hormones, prolactin and SHBG (Sweden). Cancer Causes \& Control 14 599-607. (doi:10.1023/A:1025671317220)

McNamara KM, Harwood DT, Simanainen U, Walters KA, Jimenez M \& Handelsman DJ 2010 Measurement of sex steroids in murine blood and reproductive tissues by liquid chromatography tandem mass spectrometry. Journal of Steroid Biochemistry and Molecular Biology $\mathbf{1 2 1}$ 611-618. (doi:10.1016/j.jsbmb.2010.02.001)

McNamara K, Yoda T, Miki Y, Chanplakorn N, Wongwaisayawan S, Incharoen P, Kongdan Y, Wang L, Takagi K, Mayu T et al. $2013 a$ Androgenic pathway in triple negative invasive ductal tumours: its correlation with tumour cell proliferation. Cancer Science 104 639-646. (doi:10.1111/cas.12121)

McNamara KM, Nakamura Y, Miki Y \& Sasano H 2013b Phase two steroid metabolism and its roles in breast and prostate cancer patients. Frontiers in Endocrinology 4 116. (doi:10.3389/fendo.2013.00116)

McNamara KM, Yoda T, Nurani AM, Shibahara Y, Miki Y, Wang L, Nakamura Y, Suzuki K, Yang Y, Abe E et al. 2014 Androgenic pathways in the progression of triple-negative breast carcinoma: a comparison between aggressive and non-aggressive subtypes. Breast Cancer Research and Treatment 145 281-293. (doi:10.1007/s10549-014-2942-6)

Mester J \& Eng C 2013 When overgrowth bumps into cancer: the PTENopathies. American Journal of Medical Genetics. Part C, Seminars in Medical Genetics 163C 114-121. (doi:10.1002/ajmg.c.31364)

Micello D, Marando A, Sahnane N, Riva C, Capella C \& Sessa F 2010 Androgen receptor is frequently expressed in HER2-positive, ER/PRnegative breast cancers. Virchows Archiv 457 467-476. (doi:10.1007/ s00428-010-0964-y)

Micheli A, Muti P, Secreto G, Krogh V, Meneghini E, Venturelli E, Sieri S, Pala V \& Berrino F 2004 Endogenous sex hormones and subsequent breast cancer in premenopausal women. International Journal of Cancer 112 312-318. (doi:10.1002/ijc.20403)

Missmer SA, Eliassen AH, Barbieri RL \& Hankinson SE 2004 Endogenous estrogen, androgen, and progesterone concentrations and breast cancer risk among postmenopausal women. Journal of the National Cancer Institute 96 1856-1865. (doi:10.1093/jnci/djh336)

Moinfar F, Okcu M, Tsybrovskyy O, Regitnig P, Lax SF, Weybora W, Ratschek M, Tavassoli FA \& Denk H 2003 Androgen receptors frequently are expressed in breast carcinomas: potential relevance to new therapeutic strategies. Cancer 98 703-711. (doi:10.1002/cncr.11532)

Moore NL, Buchanan G, Harris JM, Selth LA, Bianco-Miotto T, Hanson AR, Birrell SN, Butler LM, Hickey TE \& Tilley WD 2012 An androgen receptor mutation in the MDA-MB-453 cell line model of molecular apocrine breast cancer compromises receptor activity. Endocrine-Related Cancer 19 599-613. (doi:10.1530/ERC-12-0065)

Mrklic I, Pogorelic Z, Capkun V \& Tomic S 2012 Expression of androgen receptors in triple negative breast carcinomas. Acta Histochemica 115 344-348. (doi:10.1016/j.acthis.2012.09.006)

Mueller A \& Gooren L 2008 Hormone-related tumors in transsexuals receiving treatment with cross-sex hormones. European Journal of Endocrinology 159 197-202. (doi:10.1530/EJE-08-0289)

Naderi A \& Hughes-Davies L 2008 A functionally significant cross-talk between androgen receptor and ErbB2 pathways in estrogen receptor negative breast cancer. Neoplasia 10 542-548.

Naderi A, Chia KM \& Liu J 2011 Synergy between inhibitors of androgen receptor and MEK has therapeutic implications in estrogen receptornegative breast cancer. Breast Cancer Research 13 R36. (doi:10.1186/ bcr2858)

Naderi A, Meyer M \& Dowhan DH 2012 Cross-regulation between FOXA1 and ErbB2 signaling in estrogen receptor-negative breast cancer. Neoplasia 14 283-296.

Nagasaki S, Miki Y, Akahira J, Suzuki T \& Sasano H 2009 17ß-hydroxysteroid dehydrogenases in human breast cancer. Annals of the New York Academy of Sciences 1155 25-32. (doi:10.1111/j.1749-6632. 2008.03682.x)

Need EF, Selth LA, Harris TJ, Birrell SN, Tilley WD \& Buchanan G 2012 Research resource: interplay between the genomic and transcriptional networks of androgen receptor and estrogen receptor $\alpha$ in luminal breast cancer cells. Molecular Endocrinology 26 1941-1952. (doi:10.1210/ me.2011-1314)

Neve RM, Chin K, Fridlyand J, Yeh J, Baehner FL, Fevr T, Clark L, Bayani N, Coppe JP, Tong F et al. 2006 A collection of breast cancer cell lines for the study of functionally distinct cancer subtypes. Cancer Cell $\mathbf{1 0}$ 515-527. (doi:10.1016/j.ccr.2006.10.008)

Ni M, Chen Y, Lim E, Wimberly H, BaileyST, Imai Y, Rimm DL, Liu XS \& Brown M 2011 Targeting androgen receptor in estrogen receptor-negative breast cancer. Cancer Cell 20 119-131. (doi:10.1016/j.ccr.2011.05.026) 
Ni M, Chen Y, Fei T, Li D, Lim E, Liu XS \& Brown M 2013 Amplitude modulation of androgen signaling by c-MYC. Genes and Development 27 734-748. (doi:10.1101/gad.209569.112)

Niemeier LA, Dabbs DJ, Beriwal S, Striebel JM \& Bhargava R 2010 Androgen receptor in breast cancer: expression in estrogen receptor-positive tumors and in estrogen receptor-negative tumors with apocrine differentiation. Modern Pathology 23 205-212. (doi:10.1038/modpathol.2009.159)

Ochnik AM, Moore NL, Jankovic-Karasoulos T, Bianco-Miotto T, Ryan NK, Thomas MR, Birrell SN, Butler LM, Tilley WD \& Hickey TE 2014 Antiandrogenic actions of medroxyprogesterone acetate on epithelial cells within normal human breast tissues cultured ex vivo. Menopause 21 79-88. (doi:10.1097/GME.0b013e3182936ef4)

Ogawa Y, Hai E, Matsumoto K, Ikeda K, Tokunaga S, Nagahara H, Sakurai K, Inoue T \& Nishiguchi Y 2008 Androgen receptor expression in breast cancer: relationship with clinicopathological factors and biomarkers. International Journal of Clinical Oncology 13 431-435. (doi:10.1007/ s10147-008-0770-6)

Ortmann J, Prifti S, Bohlmann MK, Rehberger-Schneider S, Strowitzki T \& Rabe T 2002 Testosterone and $5 \alpha$-dihydrotestosterone inhibit in vitro growth of human breast cancer cell lines. Gynecological Endocrinology 16 113-120. (doi:10.1080/713603030)

O'Shaughnessy J, Campone M, Brain E, Neven P, Hayes DF, Bondarenko I, Griffin TW, Martin JL, De Porre P, Kheoh T et al. 2014 Randomized phase 2 study of abiraterone acetate with or without exemestane in postmenopausal patients with estrogen receptor-positive metastatic breast cancer. American Society of Clinical Oncology 2014 Annual Meeting. Journal of Clinical Oncology 32 (suppl) abstr 519.

Overmoyer B, Sanz-Altamira P, Taylor R, Hancock ML, Dalton JT, Johnston MA \& Steiner MS 2014 Enobosarm - a targeted therapy for metastatic androgen receptor positive breast cancer. American Society of Clinical Oncology 2014 Annual Meeting. Journal of Clinical Oncology 32 (suppl) abstr 568 .

Panet-Raymond V, Gottlieb B, Beitel LK, Pinsky L \& Trifiro MA 2000 Interactions between androgen and estrogen receptors and the effects on their transactivational properties. Molecular and Cellular Endocrinology 167 139-150. (doi:10.1016/S0303-7207(00)00279-3)

Park JJ, Irvine RA, Buchanan G, Koh SS, Park JM, Tilley WD, Stallcup MR, Press MF \& Coetzee GA 2000 Breast cancer susceptibility gene 1 (BRCAI) is a coactivator of the androgen receptor. Cancer Research 60 5946-5949.

Park S, Koo J, Park HS, Kim JH, Choi SY, Lee JH, Park BW \& Lee KS 2010 Expression of androgen receptors in primary breast cancer. Annals of Oncology 21 488-492. (doi:10.1093/annonc/mdp510)

Park S, Koo JS, Kim MS, Park HS, Lee JS, Lee JS, Kim SI, Park BW \& Lee KS 2011 Androgen receptor expression is significantly associated with better outcomes in estrogen receptor-positive breast cancers. Annals of Oncology 22 1755-1762. (doi:10.1093/annonc/mdq678)

Park S, Park HS, Koo JS, Yang WI, Kim SI \& Park BW 2012 Higher expression of androgen receptor is a significant predictor for better endocrine-responsiveness in estrogen receptor-positive breast cancers. Breast Cancer Research and Treatment 133 311-320. (doi:10.1007/ s10549-011-1950-z)

Parker JS, Mullins M, Cheang MCU, Leung S, Voduc D, Vickery T, Davies S, Fauron C, He X, Hu Z et al. 2009 Supervised risk predictor of breast cancer based on intrinsic subtypes. Journal of Clinical Oncology 27 1160-1167. (doi:10.1200/JCO.2008.18.1370)

Penning TM, Burczynski ME, Jez JM, Hung CF, Lin HK, Ma H, Moore M, Palackal N \& Ratnam K 2000 Human $3 \alpha$-hydroxysteroid dehydrogenase isoforms (AKR1C1-AKR1C4) of the aldo-keto reductase superfamily: functional plasticity and tissue distribution reveals roles in the inactivation and formation of male and female sex hormones. Biochemical Journal 351 67-77. (doi:10.1042/0264-6021:3510067)

Perou CM 2011 Molecular stratification of triple-negative breast cancers. Oncologist 16 (Suppl 1) 61-70. (doi:10.1634/theoncologist.2011-S1-61)

http://erc.endocrinology-journals.org DOI: 10.1530/ERC-14-0243
(C) 2014 Society for Endocrinology Printed in Great Britain
Perou CM, Sorlie T, Eisen MB, van de Rijn M, Jeffrey SS, Rees CA, Pollack JR, Ross DT, Johnsen H, Akslen LA et al. 2000 Molecular portraits of human breast tumours. Nature 406 747-752. (doi:10.1038/35021093)

Peters AA, Buchanan G, Ricciardelli C, Bianco-Miotto T, Centenera MM, Harris JM, Jindal S, Segara D, Jia L, Moore NL et al. 2009 Androgen receptor inhibits estrogen receptor- $\alpha$ activity and is prognostic in breast cancer. Cancer Research 69 6131-6140. (doi:10.1158/00085472.CAN-09-0452)

Peters KM, Edwards SL, Nair SS, French JD, Bailey PJ, Salkield K, Stein S, Wagner S, Francis GD, Clark SJ et al. 2012 Androgen receptor expression predicts breast cancer survival: the role of genetic and epigenetic events. BMC Cancer 12 132. (doi:10.1186/1471-2407-12-132)

Poulin R, Baker D \& Labrie F 1988 Androgens inhibit basal and estrogeninduced cell proliferation in the ZR-75-1 human breast cancer cell line. Breast Cancer Research and Treatment 12 213-225. (doi:10.1007/ BF01805942)

Prat A \& Perou CM 2011 Deconstructing the molecular portraits of breast cancer. Molecular Oncology 5 5-23. (doi:10.1016/j.molonc.2010.11.003)

Pristauz G, Petru E, Stacher E, Geigl JB, Schwarzbraun T, Tsybrovskyy O, Winter R \& Moinfar F 2010 Androgen receptor expression in breast cancer patients tested for BRCA1 and BRCA2 mutations. Histopathology 57 877-884. (doi:10.1111/j.1365-2559.2010.03724.x)

Qi JP, Yang YL, Zhu H, Wang J, Jia Y, Liu N, Song YJ, Zan LK, Zhang X, Zhou $\mathrm{M}$ et al. 2012 Expression of the androgen receptor and its correlation with molecular subtypes in 980 Chinese breast cancer patients. Breast Cancer 6 1-8. (doi:10.4137/BCBCR.S8323)

Qu Q, Mao Y, Fei XC \& Shen KW 2013 The impact of androgen receptor expression on breast cancer survival: a retrospective study and meta-analysis. PLoS ONE 8 e82650. (doi:10.1371/journal.pone.0082650)

Rakha EA, El-Sayed ME, Green AR, Lee AH, Robertson JF \& Ellis IO 2007 Prognostic markers in triple-negative breast cancer. Cancer 109 25-32. (doi:10.1002/cncr.22381)

Robinson JL \& Carroll JS 2012 FoxA1 is a key mediator of hormonal response in breast and prostate cancer. Frontiers in Endocrinology 368. (doi:10.3389/fendo.2012.00068)

Robinson JL, MacArthur S, Ross-Innes CS, Tilley WD, Neal DE, Mills IG \& Carroll JS 2011 Androgen receptor driven transcription in molecular apocrine breast cancer is mediated by FoxA1. EMBO Journal 30 3019-3027. (doi:10.1038/emboj.2011.216)

de Ronde W, van der Schouw YT, Pols HA, Gooren LJ, Muller M, Grobbee DE \& de Jong FH 2006 Calculation of bioavailable and free testosterone in men: a comparison of 5 published algorithms. Clinical Chemistry $\mathbf{5 2}$ 1777-1784. (doi:10.1373/clinchem.2005.063354)

Rothman MS, Carlson NE, Xu M, Wang C, Swerdloff R, Lee P, Goh VH, Ridgway EC \& Wierman ME 2011 Reexamination of testosterone, dihydrotestosterone, estradiol and estrone levels across the menstrual cycle and in postmenopausal women measured by liquid chromatography-tandem mass spectrometry. Steroids 76 177-182. (doi:10.1016/j. steroids.2010.10.010)

Sanga S, Broom BM, Cristini V \& Edgerton ME 2009 Gene expression metaanalysis supports existence of molecular apocrine breast cancer with a role for androgen receptor and implies interactions with ErbB family. BMC Medical Genomics 2 59. (doi:10.1186/1755-8794-2-59)

Santagata S, Thakkar A, Ergonul A, Wang B, Woo T, Hu R, Harrell JC, McNamara G, Schwede M, Culhane AC et al. 2014 Taxonomy of breast cancer based on normal cell phenotype predicts outcome. Journal of Clinical Investigation 124 859-870. (doi:10.1172/JCI70941)

Santen RJ, Brodie H, Simpson ER, Siiteri PK \& Brodie A 2009 History of aromatase: saga of an important biological mediator and therapeutic target. Endocrine Reviews 30 343-375. (doi:10.1210/er.2008-0016)

Sartorius G, Ly LP, Sikaris K, McLachlan R \& Handelsman DJ 2009 Predictive accuracy and sources of variability in calculated free testosterone estimates. Annals of Clinical Biochemistry 46 137-143. (doi:10.1258/acb.2008.008171)

Sasano H, Miki Y, Nagasaki S \& Suzuki T 2009 In situ estrogen production and its regulation in human breast carcinoma: from endocrinology 
to intracrinology. Pathology International 59 777-789. (doi:10.1111/ j.1440-1827.2009.02444.x)

Schippinger W, Regitnig P, Dandachi N, Wernecke KD, Bauernhofer T, Samonigg H \& Moinfar F 2006 Evaluation of the prognostic significance of androgen receptor expression in metastatic breast cancer. Virchows Archiv 449 24-30. (doi:10.1007/s00428-006-0213-6)

Scorilas A, Bharaj B, Giai M \& Diamandis EP 2001 Codon 89 polymorphism in the human $5 \alpha$-reductase gene in primary breast cancer. British Journal of Cancer 84 760-767. (doi:10.1054/bjoc.2000.1681)

Shibahara Y, Miki Y, Onodera Y, Hata S, Chan MS, Yiu CC, Loo TY, Nakamura Y, Akahira J, Ishida T et al. 2012 Aromatase inhibitor treatment of breast cancer cells increases the expression of let-7f, a microRNA targeting CYP19A1. Journal of Pathology 227 357-366. (doi:10.1002/path.4019)

Shibahara Y, Miki Y, Sakurada C, Uchida K, Hata S, McNamara K, Yoda T, Takagi K, Nakamura Y, Suzuki T et al. 2013 Androgen and androgenmetabolizing enzymes in metastasized lymph nodes of breast cancer. Human Pathology 44 2338-2345. (doi:10.1016/j.humpath.2013.04.021)

Shibuya R, Suzuki T, Miki Y, Yoshida K, Moriya T, Ono K, Akahira J, Ishida T, Hirakawa H, Evans DB et al. 2008 Intratumoral concentration of sex steroids and expression of sex steroid-producing enzymes in ductal carcinoma in situ of human breast. Endocrine-Related Cancer 15 113-124. (doi:10.1677/ERC-07-0092)

Shufelt CL \& Braunstein GD 2008 Testosterone and the breast. Menopause International 14 117-122. (doi:10.1258/mi.2008.008015)

Sieri S, Krogh V, Bolelli G, Abagnato CA, Grioni S, Pala V, Evangelista A, Allemani C, Micheli A, Tagliabue G et al. 2009 Sex hormone levels, breast cancer risk, and cancer receptor status in postmenopausal women: the ORDET cohort. Cancer Epidemiology, Biomarkers \& Prevention 18 169-176. (doi:10.1158/1055-9965.EPI-08-0808)

Soiland H, Korner H, Skaland I, Janssen EA, Gudlaugsson E, Varhaug JE, Baak JP \& Soreide JA 2008 Prognostic relevance of androgen receptor detection in operable breast cancer. Journal of Surgical Oncology $\mathbf{9 8}$ 551-558. (doi:10.1002/jso.21156)

Soreide JA, Lea OA, Varhaug JE, Skarstein A \& Kvinnsland S 1992 Androgen receptors in operable breast cancer: relation to other steroid hormone receptors, correlations to prognostic factors and predictive value for effect of adjuvant tamoxifen treatment. European Journal of Surgical Oncology 18 112-118.

Sorlie T, Perou CM, Tibshirani R, Aas T, Geisler S, Johnsen H, Hastie T, Eisen MB, van de Rijn M, Jeffrey SS et al. 2001 Gene expression patterns of breast carcinomas distinguish tumor subclasses with clinical implications. PNAS 98 10869-10874. (doi:10.1073/pnas.191367098)

Sparks R, Ulrich CM, Bigler J, Tworoger SS, Yasui Y, Rajan KB, Porter P, Stanczyk FZ, Ballard-Barbash R, Yuan X et al. 2004 UDP-glucuronosyltransferase and sulfotransferase polymorphisms, sex hormone concentrations, and tumor receptor status in breast cancer patients. Breast Cancer Research 6 R488-R498. (doi:10.1186/bcr818)

Spurdle AB, Hopper JL, Chen X, Dite GS, McCredie MR, Giles GG, Venter DJ, Southey MC, Purdie DM \& Chenevix-Trench G 2001 The steroid $5 \alpha-$ reductase type II TA repeat polymorphism is not associated with risk of breast or ovarian cancer in Australian women. Cancer Epidemiology, Biomarkers \& Prevention 10 1287-1293.

Sturgeon SR, Potischman N, Malone KE, Dorgan JF, Daling J, Schairer C \& Brinton LA 2004 Serum levels of sex hormones and breast cancer risk in premenopausal women: a case-control study (USA). Cancer Causes \& Control 15 45-53. (doi:10.1023/B:CACO.0000016574.79728.11)

Suzuki T, Darnel AD, Akahira JI, Ariga N, Ogawa S, Kaneko C, Takeyama J, Moriya T \& Sasano H $20015 \alpha$-reductases in human breast carcinoma: possible modulator of in situ androgenic actions. Journal of Clinical Endocrinology and Metabolism 862250-2257. (doi:10.1210/jcem.86.5.7444)

Suzuki T, Miki Y, Nakata T, Shiotsu Y, Akinaga S, Inoue K, Ishida T, Kimura M, Moriya T \& Sasano H 2003 Steroid sulfatase and estrogen sulfotransferase in normal human tissue and breast carcinoma. Journal of Steroid Biochemistry and Molecular Biology 86 449-454. (doi:10.1016/S0960-0760(03)00356-X)
Suzuki T, Miki Y, Nakamura Y, Moriya T, Ito K, Ohuchi N \& Sasano H 2005 Sex steroid-producing enzymes in human breast cancer. EndocrineRelated Cancer 12 701-720. (doi:10.1677/erc.1.00834)

Suzuki T, Miki Y, Moriya T, Akahira J, Ishida T, Hirakawa H, Yamaguchi Y, Hayashi S \& Sasano H $20065 \alpha$-reductase type 1 and aromatase in breast carcinoma as regulators of in situ androgen production. International Journal of Cancer 120 285-291. (doi:10.1002/ijc.22317)

Suzuki T, Miki Y, Takagi K, Hirakawa H, Moriya T, Ohuchi N \& Sasano H 2010 Androgens in human breast carcinoma. Medical Molecular Morphology 43 75-81. (doi:10.1007/s00795-010-0494-3)

Szelei J, Jimenez J, Soto AM, Luizzi MF \& Sonnenschein C 1997 Androgeninduced inhibition of proliferation in human breast cancer MCF7 cells transfected with androgen receptor. Endocrinology 138 1406-1412. (doi:10.1210/endo.138.4.5047)

Tang D, Xu S, Zhang Q \& Zhao W 2012 The expression and clinical significance of the androgen receptor and E-cadherin in triplenegative breast cancer. Medical Oncology 29 526-533. (doi:10.1007/ s12032-011-9948-2)

Tarulli GA, van Butler LM, Tilley WD \& Hickey TE 2014 Bringing androgens up a notch in breast cancer. Endocrine-Related Cancer 21 T183-T196. (doi:10.1530/ERC-14-0248)

Teulings FA, van Gilse HA, Henkelman MS, Portengen H \& AlexievaFigusch J 1980 Estrogen, androgen, glucocorticoid, and progesterone receptors in progestin-induced regression of human breast cancer. Cancer Research 40 2557-2561.

Thomas HV, Key TJ, Allen DS, Moore JW, Dowsett M, Fentiman IS \& Wang DY 1997 A prospective study of endogenous serum hormone concentrations and breast cancer risk in premenopausal women on the island of Guernsey. British Journal of Cancer 75 1075-1079. (doi:10.1038/bjc.1997.183)

Tormey DC, Lippman ME, Edwards BK \& Cassidy JG 1983 Evaluation of tamoxifen doses with and without fluoxymesterone in advanced breast cancer. Annals of Internal Medicine 98 139-144. (doi:10.7326/00034819-98-2-139)

Tsutsumi Y 2012 Apocrine carcinoma as triple-negative breast cancer: novel definition of apocrine-type carcinoma as estrogen/progesterone receptor-negative and androgen receptor-positive invasive ductal carcinoma. Japanese Journal of Clinical Oncology 42 375-386. (doi:10. 1093/jico/hys034)

Utsumi T, Yoshimura N, Takeuchi S, Ando J, Maruta M, Maeda K \& Harada N 1999 Steroid sulfatase expression is an independent predictor of recurrence in human breast cancer. Cancer Research 59 377-381.

Vera-Badillo FE, Templeton AJ, de Gouveia P, Diaz-Padilla I, Bedard PL, Al-Mubarak M, Seruga B, Tannock IF, Ocana A \& Amir E 2014 Androgen receptor expression and outcomes in early breast cancer: a systematic review and meta-analysis. Journal of the National Cancer Institute 106 djt319. (doi:10.1093/jnci/djt319)

Vihko P, Herrala A, Harkonen P, Isomaa V, Kaija H, Kurkela R, Li Y, Patrikainen L, Pulkka A, Soronen P et al. 2005 Enzymes as modulators in malignant transformation. Journal of Steroid Biochemistry and Molecular Biology 93 277-283. (doi:10.1016/j.jsbmb.2005.01.002)

Wang B, Mi M, Wang J, Wei N, Zhang Q, Zhu J, Yang S, Guo B, Xu J \& Yang X 2009 Does the increase of endogenous steroid hormone levels also affect breast cancer risk in Chinese women? A case-control study in Chongqing, China. International Journal of Cancer 124 1892-1899. (doi:10.1002/ijc.24132)

Wang Y, Romigh T, He X, Tan MH, Orloff MS, Silverman RH, Heston WD \& Eng C 2011 Differential regulation of PTEN expression by androgen receptor in prostate and breast cancers. Oncogene 30 4327-4338. (doi:10.1038/onc.2011.144)

Wang Y, He X, Yu Q \& Eng C 2013a Androgen receptor-induced tumor suppressor, KLLN, inhibits breast cancer growth and transcriptionally activates p53/p73-mediated apoptosis in breast carcinomas. Human Molecular Genetics 22 2263-2272. (doi:10.1093/ $\mathrm{hmg} / \mathrm{ddt} 077$ ) 
Wang Y, Yu Q He XJ, Romigh T, Altemus J \& Eng C 2013b Activation of AR sensitizes breast carcinomas to NVP-BEZ235's therapeutic effect mediated by PTEN and KLLN upregulation. Molecular Cancer Therapeutics 13 517-527. (doi:10.1158/1535-7163.MCT-13-0655)

Witzel I, Graeser M, Karn T, Schmidt M, Wirtz R, Schutze D, Rausch A, Janicke F, Milde-Langosch K \& Muller V 2013 Androgen receptor expression is a predictive marker in chemotherapy-treated patients with endocrine receptor-positive primary breast cancers. Journal of Cancer Research and Clinical Oncology 139 809-816. (doi:10.1007/ s00432-013-1382-8)

Yang C, Hamajima N, Iwata H, Saito T, Matsuo K, Hirose K, Inoue M, Takezaki T \& Tajima K 2002 A49T, V89L and TA repeat polymorphisms of steroid $5 \alpha$-reductase type II and breast cancer risk in Japanese women. Breast Cancer Research 4 R8. (doi:10.1186/bcr445)

Yu H, Shu XO, Shi R, Dai Q, Jin F, Gao YT, Li BD \& Zheng W 2003 Plasma sex steroid hormones and breast cancer risk in Chinese women. International Journal of Cancer 105 92-97. (doi:10.1002/ijc.11034)

Yu Q, Niu Y, Liu N, Zhang JZ, Liu TJ, Zhang RJ, Wang SL, Ding XM \& Xiao XQ 2011 Expression of androgen receptor in breast cancer and its significance as a prognostic factor. Annals of Oncology 22 1288-1294. (doi:10.1093/annonc/mdq586)

Zeleniuch-Jacquotte A, Shore RE, Koenig KL, Akhmedkhanov A, Afanasyeva Y, Kato I, Kim MY, Rinaldi S, Kaaks R \& Toniolo P 2004 Postmenopausal levels of oestrogen, androgen, and SHBG and breast cancer: long-term results of a prospective study. British Journal of Cancer 90 153-159. (doi:10.1038/sj.bjc.6601517)

Zeleniuch-Jacquotte A, Gu Y, Shore RE, Koenig KL, Arslan AA, Kato I, Rinaldi S, Kaaks R \& Toniolo P 2005 Postmenopausal levels of sex hormones and risk of breast carcinoma in situ: results of a prospective study. International Journal of Cancer 114 323-327. (doi:10.1002/ijc.20694)

Zeleniuch-Jacquotte A, Afanasyeva Y, Kaaks R, Rinaldi S, Scarmo S, Liu M, Arslan AA, Toniolo P, Shore RE \& Koenig KL 2012 Premenopausal serum androgens and breast cancer risk: a nested case-control study. Breast Cancer Research 14 R32. (doi:10.1186/bcr3117)

Zhao GL, Luu-The L, Van Fan Z, Fernand L \& Georges P 2010 Expression of $5 \alpha$-reductase type 1 in breast cancer and adjacent non-malignant tissue: an immunohistochemical study. Hormone Molecular Biology and Clinical Investigation 3 411-415. (doi:10.1515/HMBCI.2010.046)

Received in final form 18 June 2014

Accepted 19 June 2014

Made available online as an Accepted Preprint

20 June 2014 http://erc.endocrinology-journals.org DOI: 10.1530/ERC-14-0243
(C) 2014 Society for Endocrinology Printed in Great Britain
Published by Bioscientifica Ltd. 